\title{
Conservation of the Ethiopian church forests: Threats, opportunities and implications for their management
}

Open Access* version of the published article

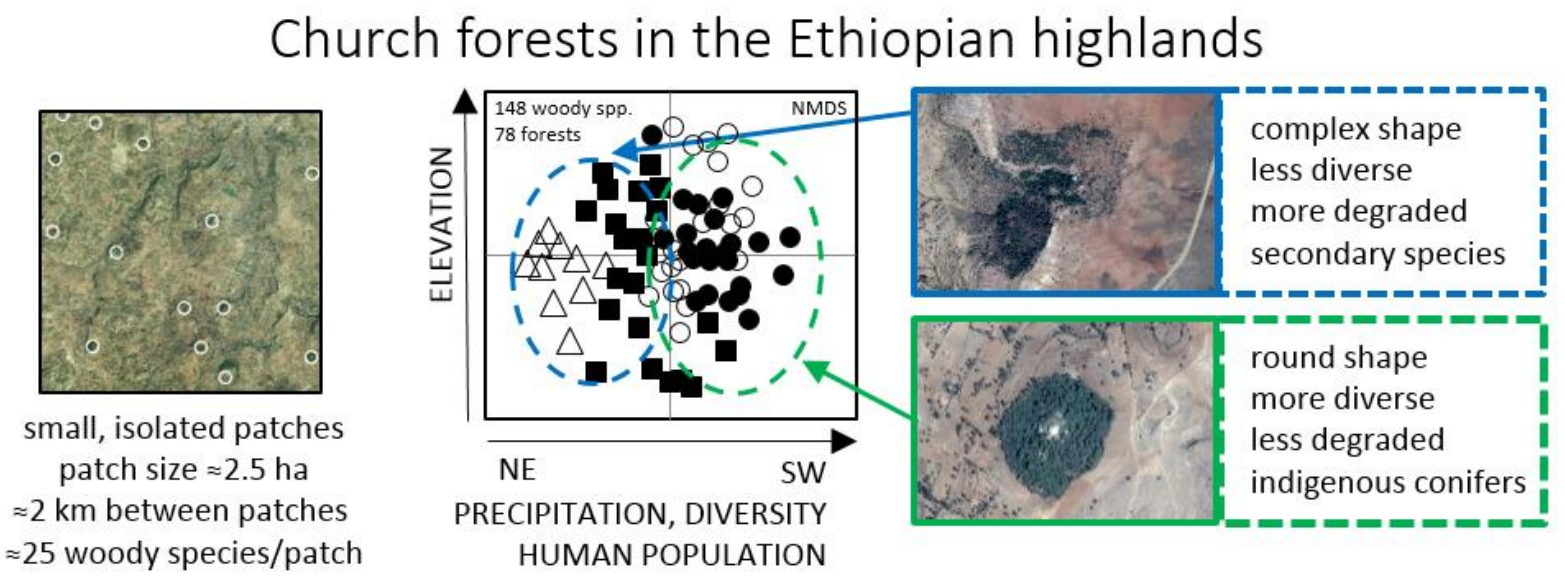

\section{Citation:}

Aerts R., Van Overtveld K., November E., Wassie A., Abiyu A., Demissew S., Daye D.D., Giday K., Haile M., TewoldeBerhan S., Teketay D., Teklehaimanot Z., Binggeli P., Deckers J., Friis I., Gratzer G., Hermy M., Heyn M., Honnay O., Paris M., Sterck F.J., Muys B., Bongers F., Healey J.R. (2016). Conservation of the Ethiopian church forests: threats, opportunities and implications for their management. Science of the Total Environment

DOI: 10.1016/j.scitotenv.2016.02.034

*Elsevier authorized the authors to post this revised personal version of the text of the final journal article on the author's institutional server, incorporating the complete citation and with a link to the Digital Object Identifier (DOI) of the article.

Creative Commons Attribution-Noncommercial-Share Alike 2.0 Belgium License

Permissions beyond the scope of this license may be available at http://www.elsevier.com/wps/find/authorsview.authors/copyright\#whatrights 


\section{Title Page}

Title

Conservation of the Ethiopian church forests: threats, opportunities and implications for their management

\section{Author names and affiliations}

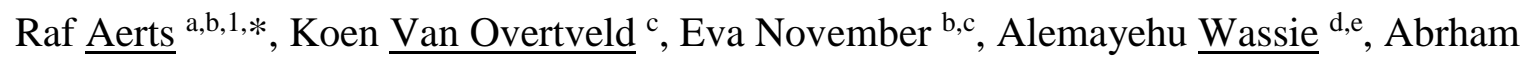

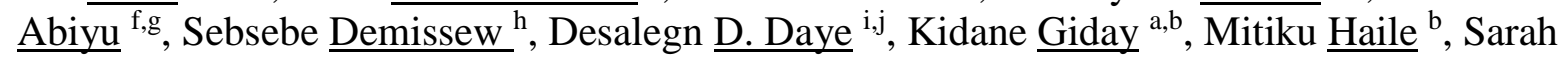
TewoldeBerhan $^{\mathrm{b}}{ }^{\mathrm{b}}$, Demel Teketay ${ }^{\mathrm{k}}$, Zewge Teklehaimanot ${ }^{\mathrm{i}}$, Pierre Binggeli $^{\mathrm{i}}{ }^{\mathrm{B}}$, Jozef Deckers ${ }^{\mathrm{c}, \text { Ib Friis }}{ }^{1}$, Georg $\underline{\text { Gratzer }}^{\mathrm{f}}$, Martin Hermy ${ }^{\mathrm{a}}$, Moïra $\underline{\text { Heyn }}^{\mathrm{a}}$, Olivier $\underline{\text { Honnay }}{ }^{\mathrm{m}}$, Maxim Paris ${ }_{n, \dagger}^{\dagger}, \overline{\text { Frank J. Sterck }}^{\mathrm{d}}$, Bart $\underline{\text { Muys }}^{\mathrm{a}}$, Frans $\underline{\text { Bongers }}{ }^{\mathrm{d}}, \underline{\text { John R. Healey }}^{\mathrm{i}}$

a Division Forest, Nature and Landscape, University of Leuven, Celestijnenlaan 200E-2411, BE-3001 Leuven, Belgium

raf.aerts@kuleuven.be (R. Aerts); kidanegg@gmail.com; kidane.giday@mu.edu.et (Kidane Giday); martin.hermy@ kuleuven.be (M. Hermy); moira.heyn @ provincieantwerpen.be (M. Heyn); bart.muys@kuleuven.be (B. Muys)

${ }^{\mathrm{b}}$ College of Dryland Agriculture and Natural Resources, Mekelle University, P.O.Box 231, Mekelle, Ethiopia

raf.aerts@kuleuven.be (R. Aerts); kidanegg@gmail.com (Kidane Giday); gualmitiku@yahoo.com (Mitiku Haile); eva.november@africamuseum.be (E. November); saratbge@gmail.com (Sara TewoldeBerhan)

${ }^{c}$ Division Soil and Water Management, University of Leuven, Celestijnenlaan 200E-2411, BE-3001 Leuven, Belgium

koenvo@hotmail.com (K. Van Overtveld); eva.november@africamuseum.be (E. November); seppe.deckers@ees.kuleuven.be (J. Deckers)

${ }^{\mathrm{d}}$ Forest Ecology and Forest Management Group, Wageningen University and Research Centre, P.O. Box 47, NL-6700 AA Wageningen, The Netherlands

alewas2008@yahoo.com (Alemayehu Wassie); frans.bongers@wur.nl (F. Bongers); frank.sterck@wur.nl (F.J. Sterck)

${ }^{\mathrm{e}}$ College of Agriculture and Environmental Sciences, Bahir Dar University, P.O. Box 5501, Bahir Dar, Ethiopia

alewas2008@yahoo.com (Alemayehu Wassie)

${ }^{\mathrm{f}}$ Institute of Forest Ecology, University of Natural Resources and Life Sciences, Peter Jordanstraße 82, A-1190 Vienna, Austria

abrham.abiyu@gmail.com (Abrham Abiyu); georg.gratzer@boku.ac.at (G. Gratzer)

g Amhara Agricultural Research Institute, P. O. Box 527, Bahir Dar, Ethiopia

abrham.abiyu@gmail.com (Abrham Abiyu)

${ }^{\mathrm{h}}$ National Herbarium, Department of Plant Biology and Biodiversity Management, Addis Ababa University, P.O. Box 3434, Addis Ababa, Ethiopia. 
sebseb.demissew@gmail.com; sebsebe.demissew@aau.edu.et (Sebsebe Demissew)

${ }^{\text {i }}$ School of Environment, Natural Resources and Geography, Bangor University, Bangor, Gwynedd, LL57 2UW, UK

desissa@yahoo.co.uk (Desalegn Desissa Daye); afs032@bangor.ac.uk (Zewge Teklehaimanot); pierre_binggeli@yahoo.co.uk (P. Binggelli); j.healey@bangor.ac.uk (J. R. Healey)

${ }^{j}$ Ethiopian Wildlife and Natural History Society, P.O.Box 13303, Addis Ababa, Ethiopia desissa@yahoo.co.uk (Desalegn Desissa Daye)

${ }^{\mathrm{k}}$ Department of Crop Science and Production, Botswana University of Agriculture and Natural Resources, Private Bag 0027, Gaborone, Botswana

dteketay@yahoo.com (Demel Teketay)

${ }^{1}$ Natural History Museum of Denmark, University of Copenhagen, Sølvgade 83, Opgang S, DK-1307 Copenhagen K, Denmark

ibf@snm.ku.dk (I. Friis)

${ }^{\mathrm{m}}$ Ecology, Evolution and Biodiversity Conservation Section, University of Leuven, Kasteelpark Arenberg 31-2435, BE-3001 Leuven, Belgium

olivier.honnay@kuleuven.be (O. Honnay)

${ }^{\mathrm{n}}$ Faculty of Engineering Technology, University of Leuven, Kleinhoefstraat 4, BE-2440 Geel, Belgium

* Corresponding author. ${ }^{1}$ Present address:

Raf Aerts, Ecology, Evolution and Biodiversity Conservation Section, University of Leuven, Kasteelpark Arenberg 31-2435, BE-3001 Leuven, Belgium. E-mail raf.aerts@ kuleuven.be, T +3216377755, F +3216321968 


\begin{abstract}
In the central and northern highlands of Ethiopia, native forest and forest biodiversity is almost confined to sacred groves associated with churches. Local communities rely on these 'church forests' for essential ecosystem services including shade and fresh water but little is known about their region-wide distribution and conservation value. We (1) performed the first large-scale spatially-explicit assessment of church forests, combining remote-sensing and field data, to assess the number of forests, their size, shape, isolation and woody plant species composition, (2) determined their plant communities and related these to environmental variables and potential natural vegetation, (3) identified the main challenges to biodiversity conservation in view of plant population dynamics and anthropogenic disturbances, and (4) present guidelines for management and policy. The 394 forests identified in satellite images were on average $\sim 2$ ha in size and generally separated by $\sim 2 \mathrm{~km}$ from the nearest neighboring forest. Shape complexity, not size, decreased from the northern to the central highlands. Overall, 148 indigenous tree, shrub and liana species were recorded across the 78 surveyed forests. Patch $\alpha$-diversity increased with mean annual precipitation, but typically only 25 woody species occurred per patch. The combined results showed that $>50 \%$ of tree species present in tropical northeast Africa were still present in the 78 studied church forests, even though individual forests were small and relatively species-poor. Tree species composition of church forests varied with elevation and precipitation, and resembled the potential natural vegetation. With a wide distribution over the landscape, these church forests have high conservation value. However, long-term conservation of biodiversity of individual patches and evolutionary potential of species may be threatened by isolation, small sizes of tree species populations and disturbance, especially when considering climate change. Forest management interventions are essential and should be supported by environmental education and other forms of public engagement.
\end{abstract}

Key words: Africa; forest fragments; landscape ecology; relic vegetation; remote sensing; sacred groves 


\section{Introduction}

Sacred groves are community-preserved, often small, forest patches in which certain spiritual, cultural or religious values contribute to the conservation of biodiversity and ecosystem services (Berkes 2009; Dudley et al. 2009; Ray et al. 2014). Sacred groves may be remnants of earlier more continuous forests or planted or regenerated forest patches in non-forest landscapes (Bhagwat et al. 2014). Because sacred groves are usually protected by local institutions or by-laws that regulate resource use (Kibet 2011), such sites are often better protected than other small habitat patches, and can therefore play an intrinsic role in biodiversity conservation (Ceperley et al. 2010; Metcalfe et al. 2010; Rutte 2011; Daye and Healey 2015). Traditionally, conservation efforts have focused either on large and relatively undisturbed habitats because large areas conserve relatively more species (Laurance 2005), or on biodiversity hotspots with exceptional concentrations of endemic species under relatively high levels of threat (Myers et al. 2000). However, conserving a number of small habitat patches such as sacred groves can have additional value for conserving biodiversity, for instance by covering a wider variety of habitats than would be achieved by protecting a few large patches of an equivalent total area (Bhagwat and Rutte 2006; Hokkanen et al. 2009) and thus contributing to higher total biodiversity covered (Benedick et al. 2006). Another important benefit is that a habitat network enabling dispersal amongst sacred groves and other protected areas (Laita et al. 2010; Chiarucci et al. 2012) may make an important contribution to genetic connectivity (Lander et al. 2010) and the survival of species as metapopulations (sensu Hanski 1998). In particular when it is not feasible to maintain large tracts of pristine habitat, for instance because the landscape is intensively used as cropland after extensive past deforestation (Arroyo-Rodríguez et al. 2009), the conservation and restoration of small habitat patches, such as sacred groves, may turn out to be the final safety net to conserve a high proportion of the landscape's previous biodiversity (Fischer and Lindenmayer 2002).

Sacred groves exist in many countries (for reviews see Bhagwat and Rutte 2006; Dudley et al. 2010), and there are well documented examples throughout Asia (e.g. Brandt et al. 2013; Gao et al. 2013; Gunaga et al. 2013; Allendorf et al. 2014) and Africa (e.g. Mgumia and Oba 2003; Campbell 2004; Sheridan and Nyamweru 2007; Kokou et al. 2008; Tankou et al. 2014). In the highlands of northern and central Ethiopia, sacred groves associated with Ethiopian Orthodox Tewahedo churches and monasteries (EOTC) are known as 'church forests'. These church forests are virtually all that is left of the Ethiopian Afromontane forest (Aerts et al. 2006; Wassie et al. 2010; Berhane et al. 2013; Jacob et al. 2014) (Fig. 1 and Fig. S1-S4) and local people rely on these church forests for the provisioning of livestock feed, tree seedlings, fuelwood, honey, clean water and other essential ecosystem services including shade, climate regulation, habitat for pollinators and spiritual values (Cardelús et al. 2012; Amare et al. 2016). In the southwest of the country, shade coffee cultivation has, until now, guaranteed that more or less natural forest remained an important land cover (Tadesse et al. 2014), despite the clear trade-off between coffee productivity and forest ecological quality (Senbeta and Denich 2006; Schmitt et al. 2010; Aerts et al. 2011; Hundera et al. 2013). In the central and northern Ethiopian highlands, however, high historical land use pressure has resulted in widespread deforestation and land degradation (Darbyshire et al. 2003; Nyssen et al. 2004). Crop land and degraded grazing land are the dominant land covers, with only very few patches of forest remaining and these are almost entirely confined to the vicinity of churches, monasteries and other holy sites such as springs. Churches manage their forests autonomously, and management varies from strict protection (with some churches surrounded by walls and patrolled by paid forest guards) to weak protection with poorly controlled harvesting of trees (Amare et al. 2016). A number of studies has evaluated the conservation value of these church forests at local scales (e.g. Aerts et al. 2006; Wassie et al. 2010; 
Berhane et al. 2013) but, to date, there is no information on the contribution of church forests to the conservation of biodiversity and ecosystem services at the larger scale, i.e. the entire Ethiopian highlands. This information is, however, urgently needed to enable the integration of these habitat patches into wider (global) conservation strategies (Dudley et al. 2009) and to understand what actions must be undertaken to conserve these forests, which are known for their exceptionally high vertebrate and plant diversity, rich in narrow-range species (Burgess et al. 2006).
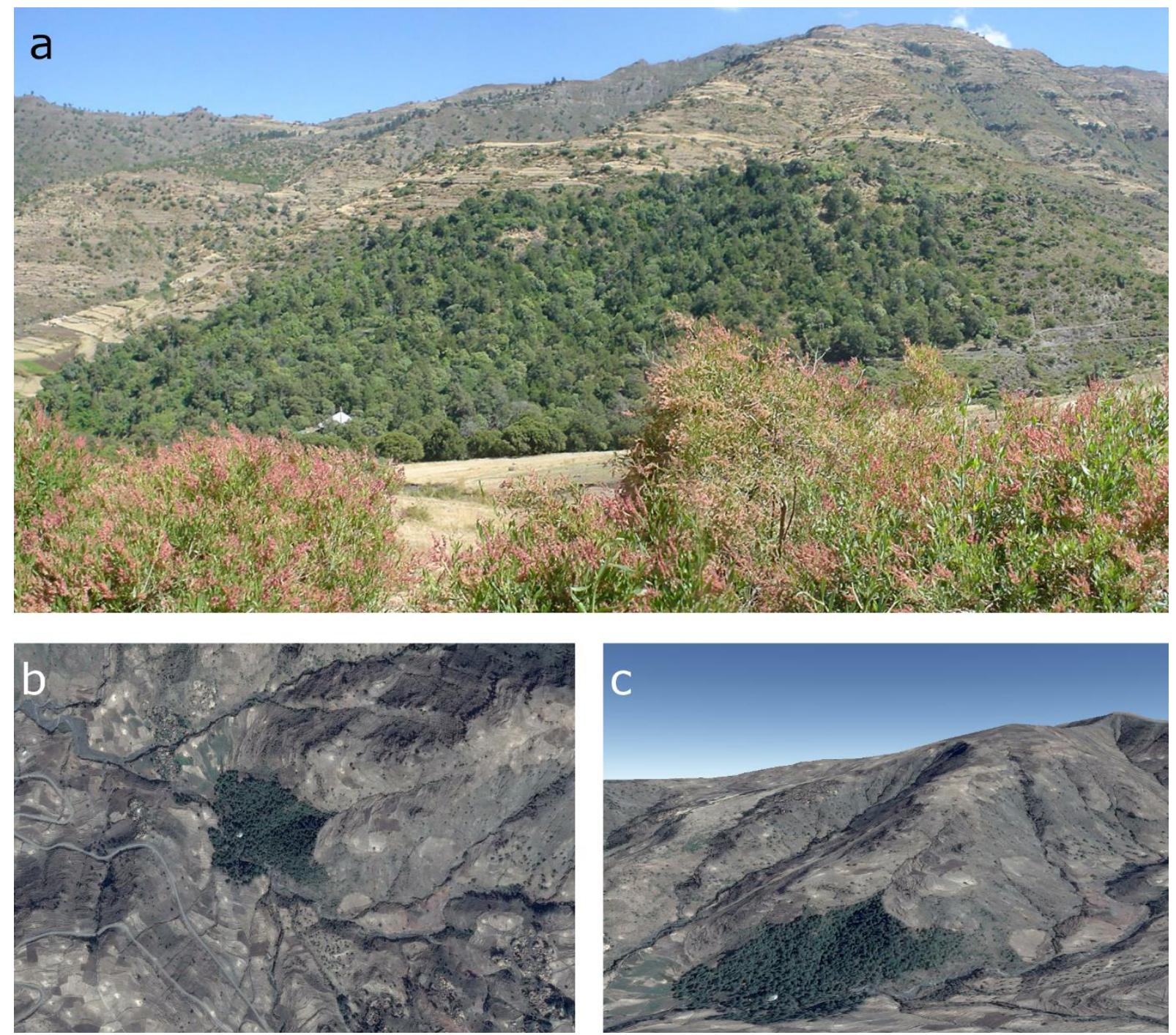

Fig. 1. Church forest C794 in the central highlands of Ethiopia $\left(12^{\circ} 24.0^{\prime} \mathrm{N} 39^{\circ} 2.6^{\prime} \mathrm{E}\right)$ :

(a) Photograph (panorama of 2 images) by Raf Aerts (16.11.2006); (b) Overhead and (c) oblique VHR satellite imagery over a global DTM in Google Earth. Satellite image @ 2014 CNES/Astrium by way of Google Earth. Eye altitude in (b) $5 \mathrm{~km}$, average patch diameter $363 \mathrm{~m}$. The observed sharp delineation of the patch in the VHR satellite image corresponds to a true sharp forest edge in the field.

The spatial arrangement and patch characteristics of church forests are important because the viability of a population within a habitat fragment or patch depends, among other factors, on the number of patches, the size of the individual patches, the isolation of the patches and the edge effects associated with the shapes of the patches (Fahrig 2003). An understanding of what woody plant communities are conserved in church forests is important because their conservation value at the regional scale depends on the species and communities that persist in the church forests and on how well these communities relate to the potential 
natural vegetation of the region. Therefore, our main research questions were the following: How do the number of church forests, their isolation, their shape and their size vary throughout the northern and central Ethiopian highlands? What are the woody species and plant communities that are conserved in the church forests? Does environmental variation contribute to differences in woody plant diversity and community composition in church forests? To that end, we (1) perform the first large-scale spatially-explicit assessment of church forests, combining remote-sensing data and the largest dataset based on field studies of church forests to date, (2) determine the woody plant communities conserved in church forests and relate diversity of church forests to environmental variables, (3) identify the main challenges to biodiversity conservation in church forests, and (4) present guidelines for management and policy to maintain and improve the forests' ecological and environmental quality and health.

\section{Methods}

\subsection{Study area}

The Ethiopian highlands consist of a region of elevated plateaus and mountain ranges with elevations over $1600 \mathrm{~m}$ above sea level which rise abruptly from the surrounding plains (Fig. 2a). The northern and central highlands, lying approximately between $10^{\circ}$ and $15^{\circ} \mathrm{N}$, are marked by deeply incised river valleys, the large Tana Lake that forms the source of the Abay or Blue Nile, and the Simien Mountains that peak at 4533 m on Mount Ras Dashen. These highlands extend between the lowlands at the southwestern shore of the Red Sea in the north, the Danakil depression and the Ethiopian Rift Valley in the east and the valley of the Upper Nile in the west.

Nyssen et al. $(2004 ; 2014)$ provided an extensive overview of the environment of the Ethiopian highlands. The climate varies with elevation, but on the plateaus rainfall is generally bimodal, with a short and erratic February-April rainy season and a long and intensive June-September rainy season. Precipitation generally increases from east to west and from north to south, yielding a mean annual precipitation of $600 \mathrm{~mm}$ in the northeast to more than $2000 \mathrm{~mm}$ in the southwest (of the northern and central highlands). Soils vary with elevation and parent material (mainly sandstone, limestone and volcanic rock) and include Cambisols over limestone and Leptosols and Vertisols over shallower or more clayey parent material, respectively.. 

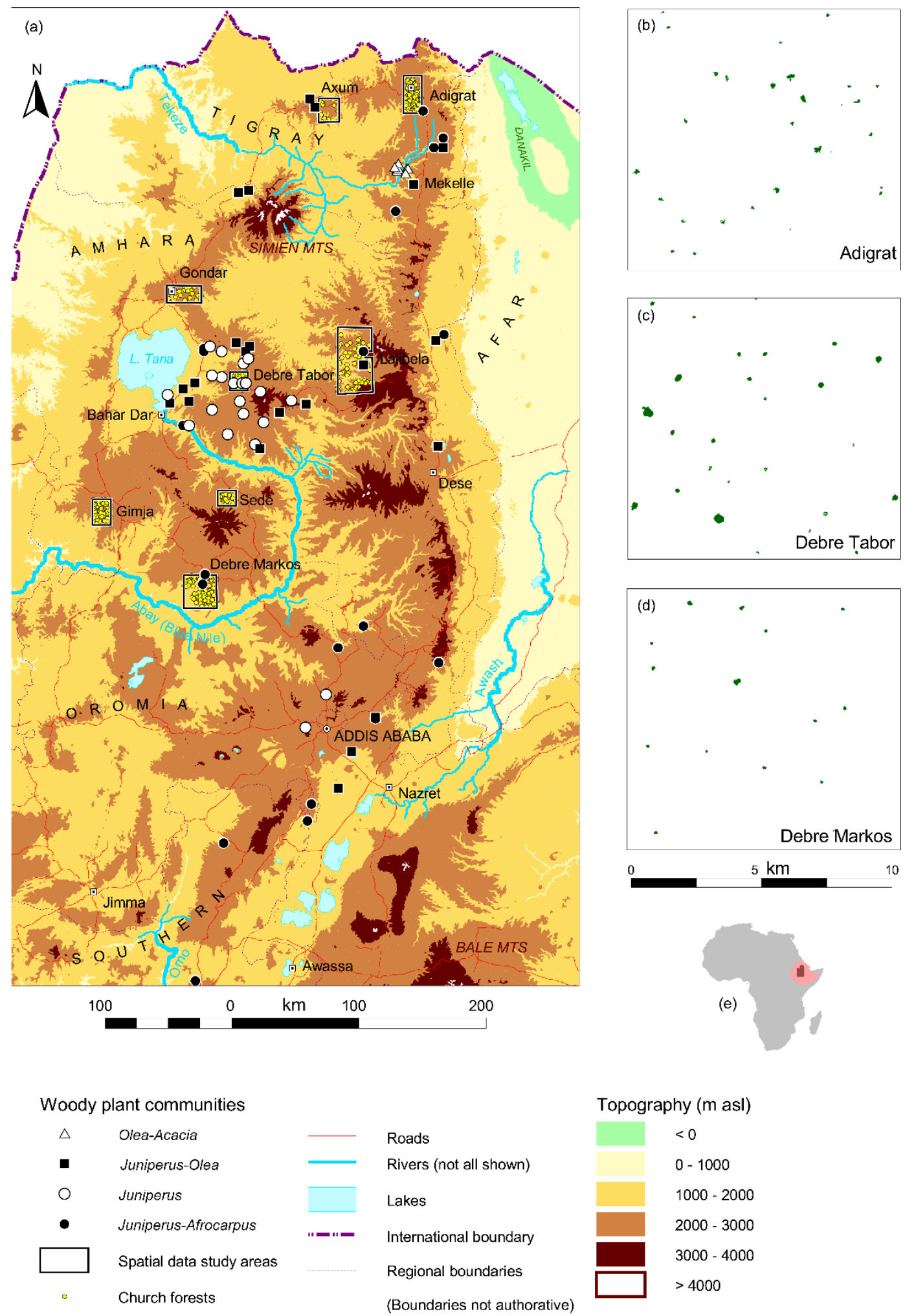

Topography (m asl)

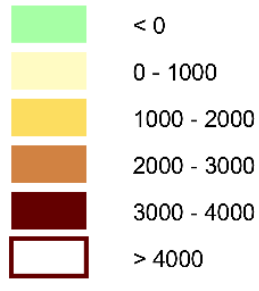

Fig. 2. Location of the sampled church forests in the highlands of northern and central Ethiopia (a) and location of the study area in Ethiopia and Africa (e). The 78 church forests sampled in the floristic survey are labeled with circles, triangles or squares to show their woody species community of the four floristically-defined groups produced by cluster and indicator species analysis (a). The larger rectangles show the location of the eight areas used for spatial data analysis; church forests are shown as small yellow circles. To illustrate the distribution of church forests in the landscape, inset maps show church forests for three $10 \times 10 \mathrm{~km}^{2}$ windows within the Adigrat (b), Debre Tabor (c) and Debre Markos (d) areas. 
Pollen records indicate the prevalence of the Afromontane forest tree species Afrocarpus falcatus (earlier known as Podocarpus falcatus), Juniperus procera and Hagenia abyssinica in the landscape prior to anthropogenic disturbance (Darbyshire et al. 2003). The potential natural vegetation (PNV), sensu Friis et al. (2010), of the highlands between 1800 and $3000 \mathrm{~m}$ altitude is the 'dry evergreen Afromontane forest and grassland complex' (DAF) in areas with rainfall below $1700 \mathrm{~mm} \cdot \mathrm{year}^{-1}$ and 'moist evergreen Afromontane forest' (MAF) in areas where rainfall exceeds $1700 \mathrm{~mm} \cdot$ year $^{-1}$. The DAF is a complex system comprising a variety of forest and woodland types, from grasslands with shrubs and trees to closed-canopy forest. Different subtypes of this forest are marked by differences in dominance of the indigenous coniferous species A. falcatus and J. procera and/or in the relative abundances of grass, shrubs or broadleaved trees present in the forest. One subtype of the DAF is the 'undifferentiated Afromontane forest', which is 'either Juniperus-Afrocarpus forest or tends towards single-species dominant Afrocarpus or Juniperus forest, both with an element of broad-leaved species' (Demissew et al. 2004). Another subtype of the DAF is the 'dry single-species dominant Afromontane forest of the Ethiopian highlands' in which 'the typical dominant species in the upper storey is Juniperus, with Olea europaea subsp. cuspidata and a number of other species below' (Demissew et al. 2004). The MAF, also known as Afromontane rainforest, has A. falcatus and Pouteria adolfi-friederici as diagnostic highland species (and, notably, no J. procera) and gradually changes into transitional rainforest at elevations below $1500 \mathrm{~m}$ (Demissew et al. 2004).

Land use in the highlands is dominated by small-scale, rain-fed agriculture, within a landscape mosaic of cropland and degraded shrub land used for livestock grazing and browsing, with sparsely distributed woodlots of planted exotic tree species (generally Eucalyptus and Cupressus species; Teketay et al. 2010), church forests, livestock grazing exclosures with recovering shrub and tree vegetation, few isolated remnant trees and wooded gullies providing tree resources in the landscape.

\subsection{Remote sensing data collection and analysis}

A two-stage sampling design was used for studying the population of church forests that occupy the northern and central highlands of Ethiopia (> $1600 \mathrm{~m}$ above sea level). In the course of the year 2010, we screened the highlands in Google Earth (GE) for very high resolution (VHR) imagery (minimum pixel resolution $0.8 \mathrm{~m}$ ) (see Fig. S1, Fig. S3) and selected eight blocks located between $36^{\circ} 49^{\prime} \mathrm{E}-39^{\circ} 33^{\prime} \mathrm{E}$ and $10^{\circ} 00^{\prime} \mathrm{N}-14^{\circ} 22^{\prime} \mathrm{N}$ (first stage), covering a total area of 440879 ha (Fig. 2a). The eight blocks were randomly selected among a larger set of candidate areas spanning a wide geographical range over the highlands. Within these blocks, all church forests were identified and digitized by systematically scanning the images visually on-screen (i.e. by means of human, visual interpretation of the images, not by automatic polygon detection) (second stage). Forest fragment perimeters and the locations of buildings (church or monastery) within each fragment were digitized (Fig. S5).

Spatial data were then analyzed using Patch Analyst 3.1 (R. Rempel, http://www.cnfer.on.ca/SEP/patchanalyst/) and a nearest-feature extension (Jenness Enterprises, http://www.jennessent.com/arcview/nearest_features.htm) implemented in ArcView GIS 3.2 (ESRI, Redlands, CA). For each fragment we calculated patch properties that were expected to be related to patch biodiversity (see Fahrig 2003): patch size (ha) (a measure of habitat size, with larger habitats expected to be more diverse), perimeter $(\mathrm{m})$, perimeter:area ratio $\left(\mathrm{m} \mathrm{ha}^{-1}\right)$, Patton shape index SI, fractal dimension FD (with higher values 
of these measures indicating potentially stronger edge effects and negative consequences for forest specialist species), distance to the nearest and second-nearest neighboring fragment (measures of isolation, with increasing isolation expected to have negative consequences for the fitness of plant populations and ultimately on species diversity) and the distance between the church and the center of the fragment (a measure that differentiates between simple, round patches with a central building and more complex forest shapes, potentially related to the genesis of these forests). We defined forest 'core area' as the central section of the forest patch where edge effects are presumed to be absent by subtracting an inward buffer of $50 \mathrm{~m}$ (with $50 \mathrm{~m}>$ three average tree heights, the buffer dimension generally used to determine forest edge area; Harris 1984). The steep slopes in the highlands mean that strong meteorological differences can exist between north- and south-facing slopes, with southfacing slopes receiving more solar insolation, potentially increasing local heat and water stress. We therefore used a 200-m digital terrain model from the EthioGIS geospatial data compilation (CDE, 1999) to determine slope angle and slope aspect $\theta$, which we transformed to a relative measure for heat load (HL, higher values indicate higher heat and water stress) using the equation $\mathrm{HL}=[1-\cos (\theta)] / 2$ (McCune and Keon 2002). The patch variables were correlated with forest fragment coordinates to detect geographic variation in patch characteristics.

The average number of church forests per 1000 ha and the average patch size of the church forests were used to estimate the total number of church forests throughout the Ethiopian highlands and the total forest cover conserved in these church forests.

\subsection{Vegetation data collection and analysis}

Original vegetation data were obtained from five different field studies covering a total of 78 unique sites (Fig 1a): Aerts et al. (2006), 10 forests, 31 20×20m plots; Aynekulu et al. (2012), 1 forest, $2950 \times 50 \mathrm{~m}$ plots; TewoldeBerhan (2003), 1 forest, $1610 \times 10 \mathrm{~m}$ plots; Teklehaimanot et al. (2004), 38 forests, plotless inventory data; Wassie et al. (2010), 28 forests, $81010 \times 10 \mathrm{~m}$ plots. The main criteria for including forest patches in the sampling strategy used across the studies included accessibility, permission and local knowledge of forest presence. From the pool of available forests, individual studies sampled forests to encompass different patch sizes and different local environments based on random sampling after local stratification. The vegetation data were used to construct species lists of woody plants (trees, shrubs and lianas, including Dracaena species and palms but excluding exotic species because we focus on conservation of indigenous vegetation). Because differences in plot sizes potentially led to differences in species richness as the probability of finding additional species increases with increasing plot size, we aggregated data to fragment level to produce a single list of the species recorded as present for each church forest. With this conversion, information about species' relative abundances was lost, but it minimized the potential bias caused by the species-area relationship and enabled calculation of reliable floristic distance measures across studies. Any differences found amongst forests are consequently caused by differences in species composition, not abundance. The final dataset contained presence/absence information of 148 indigenous tree, shrub and liana species for 78 forests.

Geographic location (coordinates north and east, elevation), site environment variables (mean annual precipitation, distance to nearest river, slope and aspect transformed into heat load) and indices of human impact (distances to nearest road and nearest town, total urban and rural population of nearest town) were recorded for each forest through overlay and nearest feature operations on the EthioGIS (CDE, Bern) datasets in ArcView GIS. The map of the 
potential natural vegetation of Ethiopia (Friis et al. 2010) was used to compare church forest vegetation to potential natural vegetation zones. Patch alpha diversity was correlated with forest fragment coordinates and environmental variables using Spearman rank correlation.

For the classification of the woody plant communities in the sampled church forests, an indirect gradient approach was adopted. To identify plant communities, church forests were clustered into $k=2-6$ groups using a Sørensen distance measurement and flexible beta linkage $(\beta=-0.25)$ (McCune and Mefford 1999). To identify the most informative number of plant communities (clusters), we used Indicator Species Analysis (Dufrêne and Legendre 1997) and calculated indicator values for all $N$ species, their individual significance $P_{i}$ and the overall mean significance $\Sigma P_{i} / N$ for each of the $k$ cluster steps. The first cluster step where the overall mean significance reached a local minimum was considered the most informative. Homogeneity within groups was tested with a multiresponse permutation procedure (MRPP) test. For MRPP, we used the Sørensen distance measure and a natural group weighting factor $n_{i} / \sum n_{i}$ (where $n_{i}$ is the number of samples in each group). In MRPP, the test statistic $T$ describes the separation between groups and the chance-corrected within-group agreement $A$ describes within-group homogeneity compared to a random expectation. If the emerging groups are significantly more homogeneous than expected by chance, then $1>A>0$ (McCune and Mefford, 1999). Nonmetric multidimensional scaling (NMDS) based on the Sørensen distance measure was used to investigate the gradients potentially influencing species distribution. NMDS was run using starting coordinates from a preliminary solution, two final dimensions, 250 iterations, an instability criterion of $10^{-5}$ and a rotation for maximum variance (McCune and Mefford 1999). To interpret the NMDS axes, which are linear combinations of plant species but expected to reflect environmental gradients, Spearman rank correlation coefficients were calculated between the NMDS scores obtained and the recorded environmental variables. Correlations were evaluated after Bonferroni correction for multiple tests.

Relative frequencies of species within communities were used to construct rankfrequency curves, which give information on the relative frequency and diversity within communities. Steep curves indicate that few species have a wide distribution (few species present in many samples) and that species composition varies considerably between samples (high beta diversity: many species present in only a few samples). Less steep curves indicate higher evenness between samples (more species present in many samples). To evaluate the spatial distribution of plant communities, we tested our dataset for isolation by distance, i.e. for a Mantel correlation between pairwise Sørensen dissimilarity indices and pairwise geographical distances.

Classification, ordination and statistical tests were conducted using PC-ORD 5.0 for Windows (MjM Software, Gleneden Beach, OR). All other statistical analyses were performed in SPSS 15.0 for Windows (SPSS Inc., Chicago, IL). The nomenclature follows the Flora of Ethiopia and Eritrea, Vol. 1-8 (1989-2009). 


\section{Results}

\subsection{Spatial distribution and patch characteristics of church forests}

A total of 402 church forests were identified in the $0.44 \times 10^{6}$ ha area of land surveyed using remote sensing (Fig. 2). Of these forests, 394 were located in the dry evergreen Afromontane forest and grassland complex zone (DAF; $1800-3000 \mathrm{~m}$, annual precipitation $<1700 \mathrm{~mm} \mathrm{yr}^{-}$ $\left.{ }^{1}\right)$, which was the focus of the study. Five forests were located in higher elevation zones three in the ericaceous belt (3000-3200 m) and two in the afro-alpine belt (> $3200 \mathrm{~m})$. Three forests were located near the lower limit of the DAF in the Combretum-Terminalia woodland and wooded grassland zone.

Within the DAF zone $(N=394$ forests sampled), the forests were consistently small with remarkably similar surface area (mean and SE mean: $2.48 \pm 0.24$ ha) and on average separated by $1.92 \pm 0.06 \mathrm{~km}$ from the nearest neighboring church forest (Table 1; Fig. S3). Church forests were sparsely distributed, with on average (over all inventoried study blocks) only $0.99 \pm 0.18$ forests per $1000 \mathrm{ha}\left(10 \mathrm{~km}^{2}\right)$. Based on an internal buffer of $50 \mathrm{~m}$, only 149 fragments (38\%) had a forest core area, with an average size of $1.32 \pm 0.29$ ha.

The perimeter-area ratio, shape index and fractal dimension of the church forests decreased towards the west and towards the south, indicating a gradient of decreasing shape complexity, but not size, from NE to SW (Fig 1b-d). Along the same gradient, the terrain slope became less steep, and the position of the church within the forest fragment changed from a position near the edge (Fig. S2) towards a more central position (Fig. S4) (Table 2).

\section{Table 1}

Patch characteristics of church forests in the dry evergreen Afromontane forest and grassland complex zone of the northern and central highlands of Ethiopia, sampled by remote sensing $(N=394)$.

\begin{tabular}{lll}
\hline & Mean & SE mean \\
\hline Area (ha) & 2.48 & 0.24 \\
Perimeter (m) & 737 & 37 \\
Perimeter:area ratio $\left(\mathrm{m} \mathrm{m}^{-2}\right)$ & 0.055 & 0.002 \\
Patton shape index & 1.512 & 0.026 \\
Patch fractal dimension & 1.351 & 0.002 \\
Distance to nearest neighboring patch (m) & 1923 & 58 \\
Distance to second nearest neighboring patch (m) & 2766 & 70 \\
Distance between church and patch centroid (m) & 48 & 4 \\
\hline
\end{tabular}


Table 2

Geographical variation of patch characteristics of church forests in the dry evergreen Afromontane forest and grassland complex zone in the northern and central highlands of Ethiopia $(N=394)$.

\begin{tabular}{lllll}
\hline & \multicolumn{2}{l}{ west to east } & \multicolumn{2}{l}{ south to north } \\
\cline { 2 - 5 } & $R$ & $p$ & $R$ & $p$ \\
\hline Area & 0.087 & 0.085 & 0.028 & 0.580 \\
Perimeter & 0.122 & 0.016 & 0.093 & 0.064 \\
Perimeter:area ratio & $\mathbf{0 . 1 9 1}$ & $<\mathbf{0 . 0 0 1} *$ & $\mathbf{0 . 2 9 8}$ & $<\mathbf{0 . 0 0 1 *}$ \\
Patton shape index & $\mathbf{0 . 2 2 2}$ & $<\mathbf{0 . 0 0 1} *$ & $\mathbf{0 . 3 2 7}$ & $<\mathbf{0 . 0 0 1} *$ \\
Patch fractal dimension & $\mathbf{0 . 2 7 5}$ & $<\mathbf{0 . 0 0 1} *$ & $\mathbf{0 . 3 9 8}$ & $<\mathbf{0 . 0 0 1} *$ \\
Distance to nearest neighboring patch & 0.046 & 0.362 & -0.130 & 0.010 \\
Distance to second nearest neighboring patch & 0.141 & 0.005 & -0.050 & 0.324 \\
Distance between church and patch centroid & $\mathbf{0 . 2 0 1}$ & $<\mathbf{0 . 0 0 1} *$ & $\mathbf{0 . 1 8 8}$ & $<\mathbf{0 . 0 0 1} *$ \\
Slope & $\mathbf{0 . 3 6 2}$ & $<\mathbf{0 . 0 0 1} *$ & $\mathbf{0 . 1 9 0}$ & $<\mathbf{0 . 0 0 1 *}$ \\
Heat load & $\mathbf{- 0 . 3 1 2}$ & $<\mathbf{0 . 0 0 1 *}$ & -0.109 & 0.030
\end{tabular}

* Significant correlation. Pearson's correlation coefficients $R$ between patch metrics and patch coordinates in UTM $37 \mathrm{~N}$ ( $\mathrm{X}=$ west to east; $\mathrm{Y}=$ south to north) need to be evaluated against a corrected $\alpha_{\text {corr }}=0.005$ to assure an overall significance of $\alpha=0.05$ (Bonferroni correction for ten tests).

\subsection{Woody plant communities in church forests}

In the 78 ground-surveyed church forests, the most widespread tree species (relative frequency $f_{r}>0.5$ in 78 forests) were Olea europaea ssp. cuspidata $\left(f_{r}=0.71\right)$, Juniperus procera $\left(f_{r}=0.67\right)$ and Croton macrostachyus $\left(f_{r}=0.54\right)$. Calpurnia aurea and Carissa spinarum (both $f_{r}=0.76$ ) were the most common shrub species. On average, there were 24.6 woody species per forest patch ( $\alpha$ diversity; $16.9 \%$ of the sampled species pool). For the 148 indigenous tree, shrub and liana species recorded across the 78 forests, each species occurred on average in $17 \%$ of the forests. Patch alpha diversity increased with increasing mean annual precipitation $\left(r_{s}=0.486, p<0.001\right)$, a gradient overlapping a geographical gradient from northeast to southwest (north: $r_{s}=-0.477, p<0.001$; east $r_{s}=-0.480, p<0.001$ ). Species dissimilarity between the forest fragments was high (overall mean Sørensen dissimilarity $71 \%$; similarity $29 \%$ ). The dissimilarity was strongly related to geographical distance between fragments, indicating a strong isolation-by-distance effect (Mantel $t=7.307, p<$ $0.001)$.

Clustering the sample plots in four floristically-defined groups provided the most informative solution with respect to plant communities (Table 3; Table S1). The separation between groups and homogeneity within objective clusters were higher than could be expected by chance (MRPP $\mathrm{T}=-28.13 ; \mathrm{A}=0.15 ; \mathrm{p}<0.001$ ). Two plant communities belonged to the dry single-species-dominant Afromontane forest of the Ethiopian highlands. The first community was a degraded subtype which could be called Olea forest with Acacia and drought-resistant shrubs (Olea-Acacia) (10 forests, in total 30 species, $1779-2362 \mathrm{~m}$ elevation range in our sample); the second community was typical dry Afromontane forest 
dominated by Juniperus with Olea and other species as secondary species (Juniperus-Olea) (22 forests, 109 species, 1490-2980 m). The two other plant communities were classified as undifferentiated Afromontane forest: one community represented a subtype with Juniperus as single-dominant species, mixed with broadleaved elements (Juniperus) (21 forests, 113

species, 1816-3111 m); the other community was the more typical undifferentiated forest with both Juniperus and Afrocarpus, mixed with broadleaved elements (Juniperus-Afrocarpus) (23 forests, 107 species, 1650-2700 m). The Olea-Acacia forest had the least species. Both the Olea-Acacia and the Juniperus-Olea forests had a low evenness of species. The undifferentiated Afromontane Juniperus and Juniperus-Afrocarpus forests had more species and a higher evenness (Fig. 3).

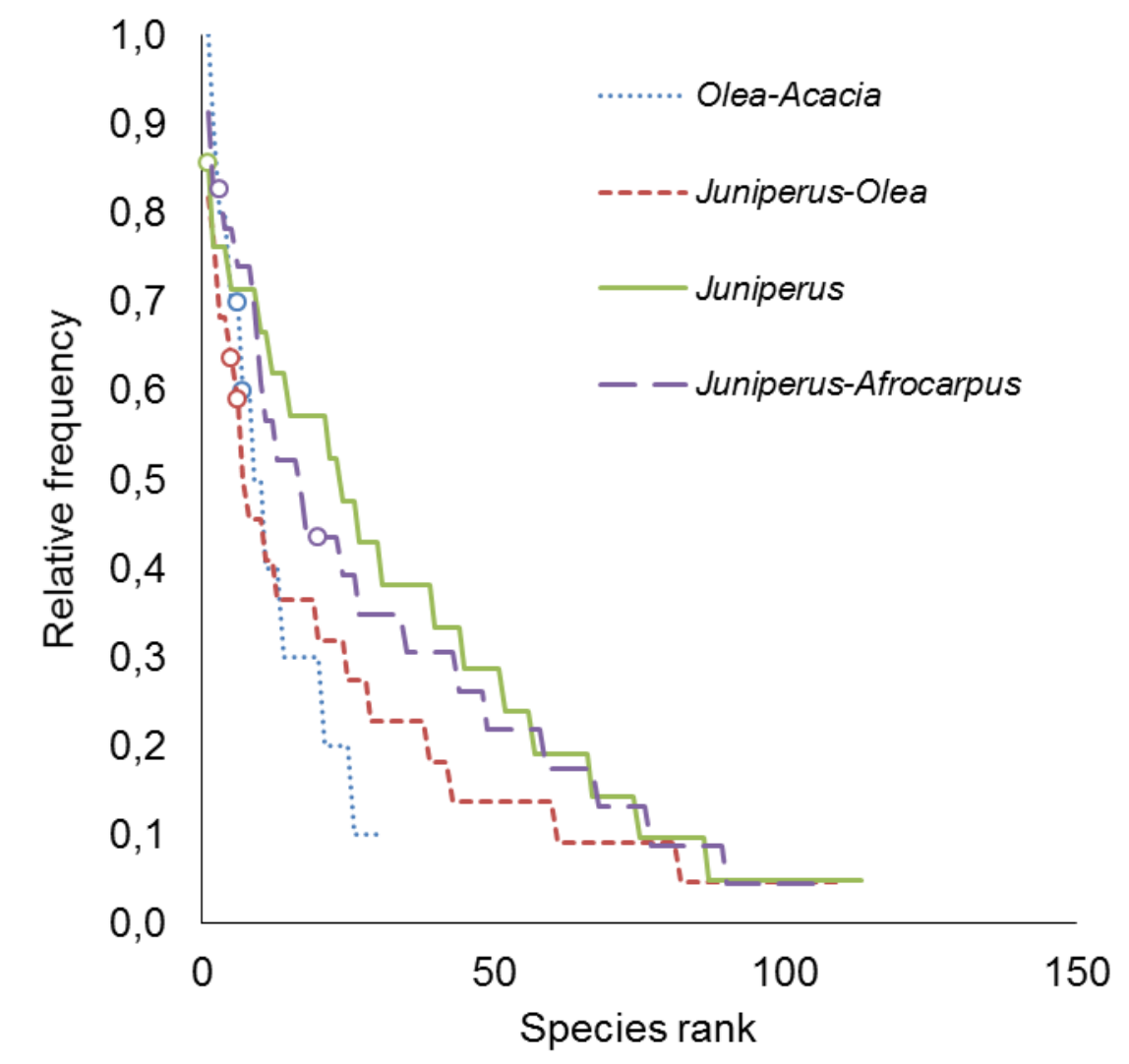

Fig. 3. Dominance-diversity curves of four floristically-defined woody species communities determined by cluster and indicator species analysis of 78 church forests in Ethiopia. Steep curves indicate dominance (as measured by relative frequency) by relatively few species; curve length along the horizontal axis is directly related to community $\gamma$-diversity (total species richness). Circles indicate the positions of the species used in the names of the communities. 


\section{Table 3}

Woody species communities of 78 surveyed church forests in the dry evergreen Afromontane forest and grassland complex zone of the northern and central highlands of Ethiopia produced by cluster and indicator species analysis. For each community, the ten most frequent woody species are listed with their relative frequency. Frequencies for the Afromontane conifers are also given in the bottom two rows where they are not in the ten most frequent species.

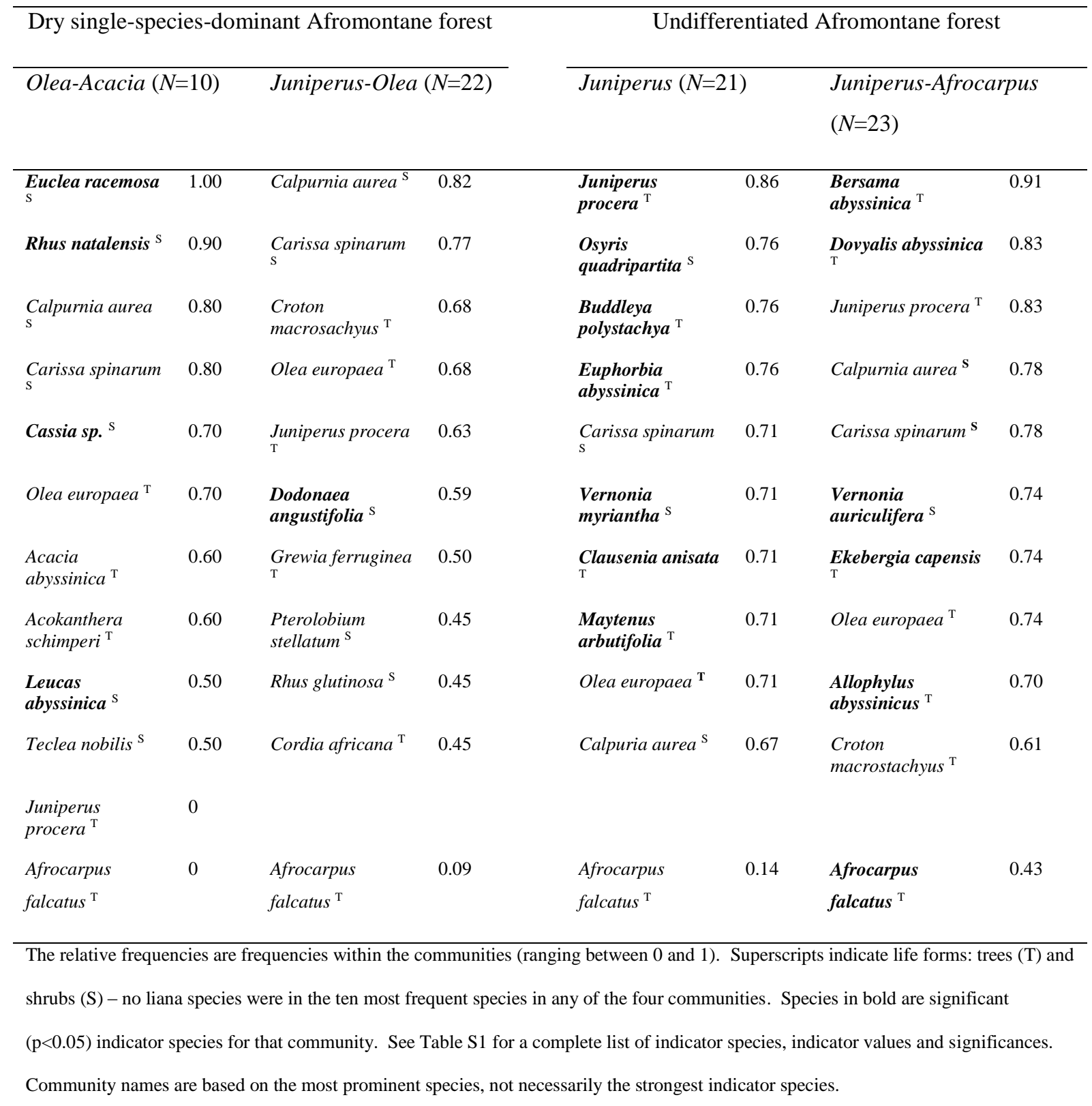

In the NMDS ordination (cumulative $\mathrm{R}^{2}=0.643$ ), degraded Olea-Acacia and JuniperusOlea forests were partitioned from the other dry Afromontane forests along the first dimension (38.0\% of variance explained), which represented a geographical gradient (northeast to southwest), coinciding with a gradient of increasing rainfall, increasing urban and rural population and decreasing distance to towns (Fig. 4; Table S2). The second 
dimension (26.3\% of variance explained) represented an altitudinal gradient of increasing elevation (Fig. 4; Table S2).

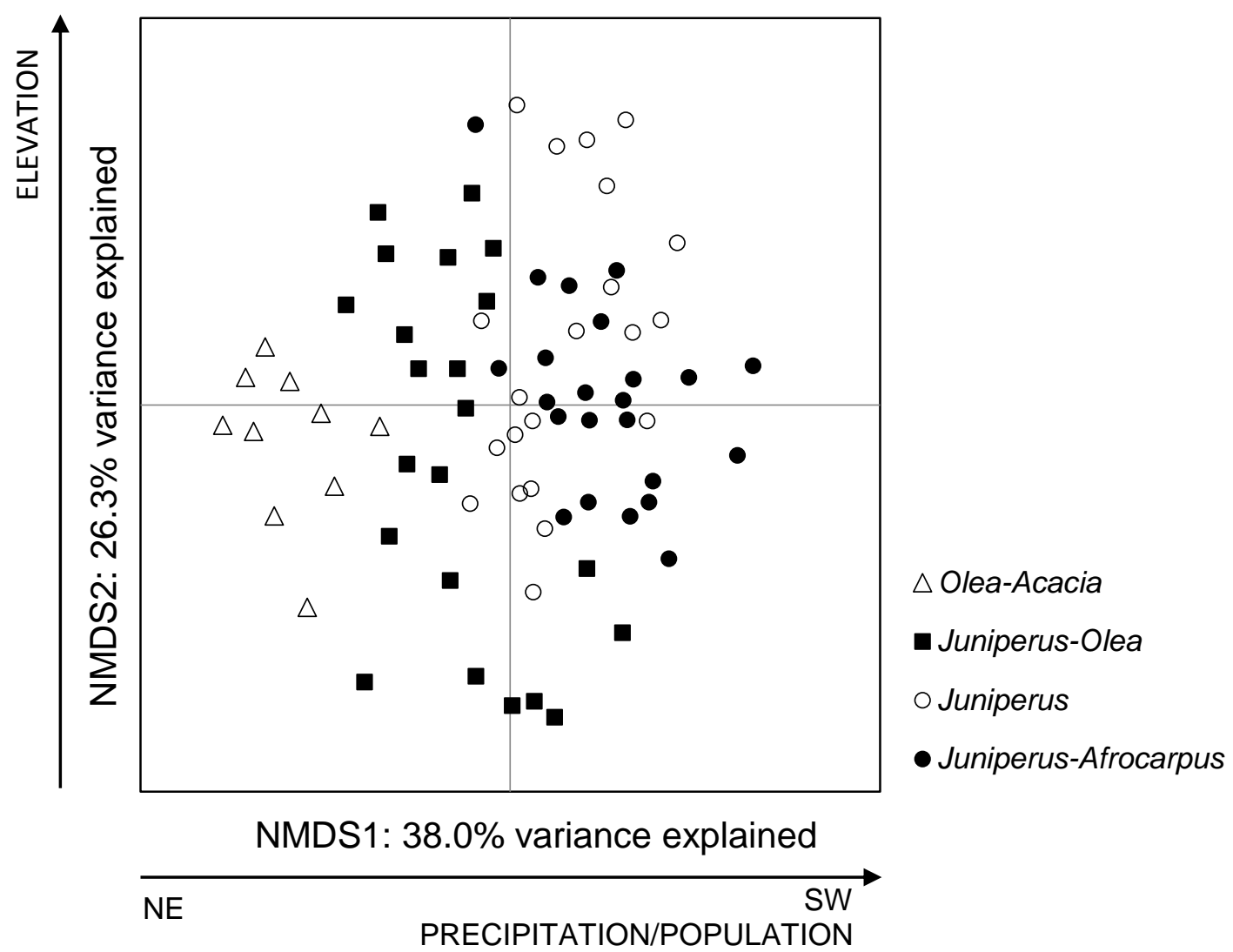

Fig. 4. Ordination of 78 church forests in the northern and central highlands of Ethiopia based on nonmetric multidimensional scaling (NMDS) of tree and shrub species occurrence. Forests are labeled according to woody species communities produced by cluster and indicator species analysis. The mean annual precipitation gradient in our sample ranges between 550 and $1950 \mathrm{~mm}$; the elevation gradient between 1490 and $3111 \mathrm{~m}$ above sea level.

\section{Discussion}

\subsection{Remote sensing data reveal numerous small, isolated forests}

The remote sensing data revealed that individual church forests were typically small with little or no forest core area free from edge effects. The complexity of the forest shapes decreased from NE to SW. More regularly shaped patches are usually related to lower negative edge effects and increased core habitat quality (Fahrig 2003), but the less complex (i.e. round) forests featured more centrally located churches and were located in more densely populated areas and this obviously also negatively affects core habitat ecological quality (Fig. S4).

The nearest neighbor distance between patches was $\sim 2 \mathrm{~km}$ but the patch density was only one forest per 1000 ha. This indicates that the patch distribution is not entirely uniform, as in a perfectly organized grid a nearest neighbor distance of $2 \mathrm{~km}$ would yield a patch density of one forest per 400 ha. Given a total area of $19.4 \times 10^{6}$ ha potentially covered by 
DAF (Friis et al. 2010) and a density of $\sim 1$ forest fragment per 1000 ha, and assuming that there is no bias in the location of the eight surveyed areas, the estimated number of church forests throughout the Ethiopian highlands potentially covered by DAF is 19400 . This is probably a conservative estimate, as a government report mentions a total of 35000 churches throughout the highlands (IBC 2012). The extrapolated total cover of forest estimated to be conserved in our estimated 19400 church forests (95\% confidence interval, not including other forest remnants) throughout the Ethiopian highlands is $\sim 39000-57000$ ha. This total amounts to merely $0.20-0.30 \%$ of the land that could potentially be covered by DAF. In comparison, an estimated total of 102000 ha of high forest exists throughout Amhara and Tigray regions, the two main regions of the studied highlands (WBISPP 2004). Throughout Ethiopia, an estimated 4 million ha of high forest persists to date, but the vast majority of these forests (3.9 million ha) are moist forests in the southwestern regions of the country (WBISPP 2004). Church forests thus contribute to regional conservation of DAF, not by conserving a large amount of habitat (the cumulative habitat area is rather small, especially when compared with the moist forests), but rather by conserving a large number of patches, well distributed throughout the region, and covering the widest possible range of environmental conditions.

\subsection{Field survey data reveal high floristic variability}

The vegetation in the sampled church forests could be classified into four plant communities which are phases of the DAF that vary with rainfall and geographical gradients. Nevertheless, species dissimilarities or beta species diversity amongst individual church forests were high. Individual species occurred on average in only 13 out of the 78 sampled forest patches . Similar and even lower occurences of tree species have been found in other sets of small tropical forest fragments, for instance in tropical rainforest fragments in Los Tuxtlas, Mexico, where $41 \%$ of the recorded species occurred in only one or two patches (Arroyo-Rodriguez et al. 2009), and in rainforest patches in Chiapas, Mexico, that shared on average only $27 \%$ of species (Hernandez-Ruedas et al. 2014). Individual forests were also rather species-poor, each containing on average only 25 species of woody plants or $16.9 \%$ of the sampled species pool. Nevertheless, a total of 148 indigenous woody species were observed in all patches combined, which is more than half of the ca. 270 tree species that occur in tropical northeast Africa (Friis 1992) and which is more than the numbers of woody species that are reported for the few contiguous natural forests left in the region (e.g. 43 woody species in Menagesha forest and 66 woody species in Hugumburda forest, both Juniperus-Olea forest with some scattered Afrocarpus) (Demissew 1988; Aynekulu 2011). These results highlight that Ethiopian church forests, much like other sacred forest sites in the world (Bhagwat and Rutte 2006), are important for regional forest biodiversity conservation, but also that there is a need for a region-wide conservation strategy for the church forests of the Ethiopian highlands.

As plant communities varied with rainfall and geography, the large species differences between fragments and thus high beta diversity and high species turnover in the region are most likely related to environmental variation. Dissimilarities in plant species composition could, however, also be partially attributed to differences in species extinctions between fragments as some woody species may be more susceptible than others to the detrimental effects of small population sizes in the small and isolated forests. It is known that a small population size negatively affects population genetic diversity and especially in outcrossing species (Honnay and Jacquemyn 2007; Aguilar et al. 2008). Small fragments can indeed only support small populations, and small populations are susceptible to inbreeding and random genetic drift, resulting in poor adaptive potential to changing environmental conditions, 
reduced fitness and increased probabilities of extinction (Keller and Waller 2002). Increasing shape complexity and associated deleterious edge effects may further increase the vulnerability to local extinction, in particular for forest specialist species (Murcia 1995; Bender et al. 1998; Ewers and Didham 2006). As habitat quality deteriorates through loss of woody plants in forest fragments, local extinctions of other taxa such as birds can be expected, for instance through loss of keystone species (Cordeiro et al. 2015) or increased niche competition (Visco et al. 2015). Even when species persist in forest fragments, their genetic diversity may not, and hence the long term viability of their populations may be at risk (Struebig et al. 2011). Under these circumstances the degree of functional isolation of fragments is particularly important: if dispersal amongst fragments occurs sufficiently frequently then species and their genetic diversity can survive in such habitat networks as meta-populations, despite a high rate of local extinction in individual fragments (Hanski 1998). Exchange of plant genetic material between isolated forest fragments can occur via pollen flow and via seed dispersal. Habitat fragmentation limits pollen flow of woody species, even in wind-pollinated species, hampering the replenishment of alleles that may have been lost through genetic drift in the small populations (Vranckx et al. 2012). If mating events occur mainly within fragments, between neighboring and possibly related trees, this may increase the risk of inbreeding and induce lower fitness in future generations (Vranckx et al. 2014). Although birds, including large and small frugivores such as hornbills and thrushes, are relatively well conserved in the church forests (Aerts et al. 2008), and although the regionwide establishment of grazing exclosures during the previous decades may have provided stepping stones and an improved landscape connectivity for seed vectors (Aerts et al. 2008), it is unclear to what extent these birds act as effective seed dispersal vectors. Also, if mating patterns are mainly local and offspring therefore potentially inbred, seed dispersal may have a limited genetic rescue effect and therefore it remains unclear if birds reduce functional forest isolation at all. Overall, the evolutionary potential of the woody species in the church forests can be expected to be low, jeopardizing adaptation of the populations to emerging pests and diseases such as outbreaks of Corynelia, a fungal pathogen of Afrocarpus falcatus (Assefa et al. 2014), or to changing environmental conditions such as climate change

\subsection{Combined data suggest historical legacies of past human activities}

The plant communities observed in the church forests sampled throughout the northern and central highlands of Ethiopia belonged to the dry evergreen montane forest and grassland complex and represented different spatial phases of the potential natural vegetation of the area. A geographical northeast to southwest gradient and differences in elevation separated dry single-species-dominant Afromontane forest communities (degraded Olea-Acacia forest and Juniperus-Olea forest) from richer undifferentiated Afromontane forest communities (Juniperus and Juniperus-Afrocarpus forests with broadleaved elements). The underlying driver of this distinction is most likely the increase in annual rainfall along this gradient (Table S2), with the western highlands wetter than the eastern (Crummey 2000). Higher precipitation was marked by an increase in importance of the indigenous conifers, in particular A. falcatus, and of species more typical of mesic or moist site conditions such as Albizia gummifera and Coffea arabica. In particular coffee is not an element of the potential natural vegetation, but has been planted into church forests. Also Cupressus lusitanica, Citrus spp., Eucalyptus spp., Grevillea robusta, Jacaranda mimosifolia, Melia azedarach and Pinus spp.that that were recorded in the studied forests. These species exotic to Ethiopia are commonly planted in church forests (and plantations) for their specific use values. Such species improve the benefits for local users, but may also contribute to the degradation of the natural forest by replacing indigenous trees and shrubs (Amare et al. 2016). 
Other differences in past forest use may also have contributed to the differentiation between the relatively species-poor Olea-Acacia and Juniperus-Olea forests and the other, richer communities. High-value timber species such as J. procera and A. falcatus may have become locally extinct in some intensively used patches but not in others, as also noted in fragmented Afromontane forests elsewhere (Thijs et al. 2014). In the Olea-Acacia community forests (in the northeast of the study area), the prevalence of drought-tolerant, earlysuccessional shrub species such as Euclea racemosa, Rhus natalensis and Calpurnia aurea (Table 3), and the absence of $J$. procera and A. falcatus, do suggest degradation (Aerts et al. 2006). In the Olea-Acacia community, removal of the original canopy trees (presumably $J$. procera) may have resulted in harsher microclimatic conditions, rendering these forests more similar to vegetation types of drier sites at lower elevations, such as Acacia-Commiphora woodland. Other research in the region has shown that such degradation is still ongoing, with logging, fires and tree dieback of J. procera and O. europaea ssp. cuspidata causing community shifts from dry Afromontane forest to shrubland (Aynekulu 2011).

Historical land use pressures may also have had an impact on forest species composition. Owing to high land-use pressure and widespread conversion of natural habitat to agricultural land in the northeastern highlands around 500 BC (Darbyshire et al. 2003), churches that were established in that region much later may have been placed near already isolated and degraded forest patches in a largely deforested landscape. Present-day trees may even stem from relatively recent regrowth, as evidenced by the comparison of historical and recent landscape and aerial photographs of that region (Nyssen et al. 2009; 2016). The round shape, the central position of the church, the low standard deviation of mean distance between forest patches and the spatial arrangement of churches and forests (Fig. S3, S4, S6) in the central highlands might, on the contrary, suggest systematic planning of church establishment in a landscape with more intact forest, for instance as a component of strategies to control the land (Crummey 2000). The landscape pattern of church forests is sometimes remarkably similar to a von Thünen landscape with regularly spaced markets, or to orderly spaced towns in settlement-distribution theories (see e.g. Ullman 1941). Fig. S6The structure and composition of contemporary church forest vegetation may thus primarily be a product of environmental variables and human factors, as elsewhere in Eastern Africa (Bongers and Tennigkeit 2010), but differences between forests could be enhanced by random species losses, and legacies of historical land use and institutional strategy. Future archaeological, anthropological and socio-ecological research using, among other approaches, participatory resource inventories and socio-economic surveys would provide more information on how individual decisions and group-level institutional decisions may have shaped the church forest plant communities. 


\section{Implications for forest conservation management and policy}

\subsection{Improve policy to conserve forests more efficiently}

The high floristic dissimilarities amongst individual church forests and the small population sizes mean there is little redundancy. To maintain species diversity and associated ecosystem services, a high proportion of patches needs to be conserved (see also Hernandez-Ruedas et al. 2014). This is because low frequencies of species entail high extinction risks when patches are lost, and because extinction risks are high in landscapes with low vegetation cover, low connectivity, degraded vegetation and intensive land use in the matrix (Fischer and Lindenmayer 2007).

The survival to date of so many church forests in Ethiopia is a testament to the historical and contemporary importance of the cultural, spiritual and religious values with which they are associated. Nevertheless, given that both historical and present land use rights, and religious and governmental laws apply, the legal conservation status of these forests is an extremely complex matter. Uncertainties in boundary and land ownership issues complicate conservation, especially along the edges of the forests. Providing legislative instruments that strengthen conservation and management of forests by the church and other community-based groups could strengthen Ethiopia's forest conservation strategy. These policies should aim to strengthen, not replace, local forms of forest protection (Brandt et al. 2015; Denier et al. 2015).

\subsection{Manage forests to improve forest quality and stakeholder benefits}

Not only must the number of church forests be maintained, but also the patch quality. Ideally patch quality should be improved, as in other areas where little forest remains (Turner and Corlett 1996). Locally, future management of church forests should be focused on ensuring ecological sustainability, including its synergy with the sustaining of cultural values. Rather than excluding human activities, the relevant institutions should focus on management and restoration measures that ensure the favorable conservation status of the DAF habitats and species while at the same time increasing involvement of and benefits for local communities (Amente et al. 2010; Denier et al. 2015; Amare et al. 2016). To that end, forest management should focus on (i) avoiding further encroachment and reducing unfavorable edge effects, for instance by boundary demarcation and participatory management with surrounding land users; and (ii) avoiding further internal degradation of the forest by controlling grazing, browsing and tree cutting (Wassie et al. 2009a,b).

Increasing tree cover in a surrounding buffer zone through locally appropriate agroforestry practices, including DAF tree species present in the church forests, can contribute to local livelihoods and assist in conserving biodiversity within the forest (Teketay et al. 2010; Amare et al. 2016). This would enable the development and conservation of an expanded or new forest core area within the existing boundary of the church forest. In this way the functional ecological area of the church forest would be enlarged, thus reducing the extinction risks for tree populations, without harming the livelihoods of local people dependent on this land. Spatially targeted expansion of such buffer zones and establishment of new forest patches within the matrix located at distances compatible with dispersal distances of trees may play an important role in increasing the quality of the matrix (see e.g. Lemenih and Bongers 2010; Telila et al. 2015), thereby decreasing the functional isolation of species' populations within a network of forest patches and reducing the risks of extinction (Vandermeer and Carvajal 2001; Berens et al. 2014). 
Management within the existing church forest areas should focus on ensuring healthy populations of tree species. This could be accomplished by assisting natural regeneration of extant species (in the first place by excluding livestock), and by planting nursery raised seedlings or direct seeding of species missing from that patch, thus improving their distribution among the patches (see e.g. Wassie et al. 2009a,b). A number of PNV distribution models based on edaphic factors and projected climate conditions, with or without projected fire frequency distributions in the year 2070, predict a widespread replacement of DAF by Combretum-Terminalia woodland and, to a lesser extent, by MAF in the current southern range of the DAF (van Breugel et al. 2015). Active forest management should therefore take account of current and future environmental changes and make strategic choices of species to regenerate to climate-proof the biodiversity of the church forests.

Finally, and very importantly, forest management has to be supported by environmental education (Keane et al. 2011), community-based monitoring (Dickinson et al. 2012) and other forms of public engagement required for conservation planning for multiple stakeholders (Githiru and Lens 2007; Denier et al. 2015). These may be supported by payment for ecosystem services schemes (Petheram and Campbell 2010; Amare et al. 2016; Deng et al. 2016; but see Poudyal et al. 2016). Without active involvement of all stakeholders, illegal forest use including grazing and logging will remain critical issues.

\subsection{Seek international recognition for Ethiopia's church forests}

Despite the conservation issues discussed above, the Ethiopian church forests are of outstanding universal value. This is essential for them to be included on UNESCO's World Heritage List, for which they must meet at least one out of ten selection criteria (http://whc.unesco.org/en/criteria/). The Ethiopian church forests do not meet only one but a staggering six criteria to qualify as mixed religious, natural and cultural heritage, i.e. criterion (iii), to bear a unique or at least exceptional testimony to a cultural tradition which is living; criterion (v), to be an outstanding example of human settlement and land-use which is representative of a culture, or a human interaction with the environment especially when it has become vulnerable under the impact of irreversible change; criterion (vi), to be directly associated with living traditions or with beliefs; criterion (vii), to contain areas of exceptional natural beauty; criterion (ix), to be an outstanding example representing significant on-going ecological and biological processes in the evolution and development of terrestrial ecosystems and communities of plants and animals; and criterion (x), to contain the most important and significant natural habitats for in situ conservation of biological diversity, including those containing threatened species of outstanding universal value from the point of view of conservation.

The inclusion of the church forests in the Tentative List of Ethiopian natural and cultural heritage sites (http://whc.unesco.org/en/statesparties/et) and, ultimately, its inscription on UNESCO's World Heritage List would provide timely and well-deserved recognition of the exceptional religious, natural and cultural value of Ethiopia's church forests. The management and policy issues of Ethiopian church forests have global relevance, because small and isolated forest patches and woodlots are becoming increasingly important as global deforestation and forest fragmentation continue. 


\section{Acknowledgements}

The authors wish to thank the Ethiopian Orthodox Tewahedo Church for its permission to work in its unique forests. The authors also wish to thank the numerous other organizations that provided financial or logistical support for the conduct of the scientific research of forests in Ethiopia and for the preparation of the manuscript: the Darwin Initiative (UK Department for Environment, Food and Rural Affairs), the MU-IUC programme of the Flemish Interuniversity Council (VLIR) at Mekelle University, the University Development Cooperation Programme of the Flemish Interuniversity Council (VLIR-UOS), Groneman B.V. (The Netherlands), the European Union (EU), the Commission for Development Studies (KEF), the German Academic Exchange Service (DAAD), the Austrian Exchange Service (ÖAD), the International Foundation for Science (IFS), the Christensen Fund, the KU Leuven Research Fund, the Research Foundation - Flanders (FWO), and the Ethiopian Wildlife and Natural History Society (EWNHS).

\section{Electronic supplementary material}

Satellite images and other supplementary material associated with this article can be found, in the online version, at doi:10.1016/j.scitotenv.2016.02.034.

\section{Glossary}

DAF dry evergreen Afromontane forest

MAF moist evergreen Afromontane forest

PNV potential natural vegetation

VHR very high resolution satellite imagery

NMDS non-metric multi-dimensional scaling 


\section{References}

Aguilar R, Quesada M, Ashworth L, Herrerias-Diego Y, Lobo J (2008) Genetic consequences of habitat fragmentation in plant populations: susceptible signals in plant traits and methodological approaches. Mol Ecol 17:5177-5188.

Aerts R, Hundera K, Berecha G, Gijbels P, Baeten M, Van Mechelen M, Hermy M, Muys B (2011) Semi-forest coffee cultivation and the conservation of Ethiopian Afromontane rainforest fragments. For Ecol Manage 261:1034-1041.

Aerts R, Lerouge F, November E, Lens L, Hermy M, Muys B (2008) Land rehabilitation and the conservation of birds in a degraded Afromontane landscape in northern Ethiopia. Biodiv Conserv 17:53-69.

Aerts R, Van Overtveld K, Haile M, Hermy M, Deckers J, Muys B (2006) Species composition and diversity of small Afromontane forest fragments in northern Ethiopia. Plant Ecol 187:127-142.

Allendorf TD, Brandt JS, Yang JM (2014) Local perceptions of Tibetan village sacred forests in northwest Yunnan. Biol Conserv 169:303-310.

Amare D, Mekuria W, T/wold T, Belay B, Teshome A, Yitaferu B, Tessema T, Tegegn B (2016) Perception of local community and the willingness to pay to restore church forests: the case of Dera district, northwestern Ethiopia. For Trees Livelihoods DOI: $10.1080 / 14728028.2015 .1133330$

Amente G, Huss J, Tennigkeit T, Yemshaw Y (2010) Silvicultural management of community forests towards multiple uses in the Bale Mountains of Ethiopia. In: Bongers F, Tennigkeit T (eds) Degraded Forests in Eastern Africa. Management and Restoration. Earthscan, London, pp 267-290.

Arroyo-Rodriguez V, Pineda E, Escobar F, Benitez-Malvido J (2009) Value of small patches in the conservation of plant-species diversity in highly fragmented rainforest. Conserv Biol 23:729-739.

Assefa A, Abate D, Stenlid J (2014) Characterization of Corynelia uberata Fr., a putative fungal pathogen of Podocarpus falcatus in Ethiopian forests. For Pathol 44: 45-55.

Aynekulu E (2011) Forest diversity in fragmented landscapes of northern Ethiopia and implications for conservation. Diss. Ph.D. Rheinischen Friedrich-Wilhelms-Universität Bonn. 142 pp.

Aynekulu E, Aerts R, Moonen P, Denich M, Gebrehiwot K, Vagen TG, Mekuria W, Boehmer HJ (2012) Altitudinal variation and conservation priorities of vegetation along the Great Rift Valley escarpment, northern Ethiopia. Biodiv Conserv 21:2691-2707.

Bender DJ, Contreras TA, Fahrig L (1998) Habitat loss and population decline: A metaanalysis of the patch size effect. Ecology 79:517-533.

Benedick S, Hill JK, Mustaffa N, Chey VK, Maryati M, Searle JB, Schilthuizen M, Hamer KC (2006) Impacts of rain forest fragmentation on butterflies in northern Borneo:species richness, turnover and the value of small fragments. J Appl Ecol 43:967977.

Berens DG, Chama L, Albrecht J, Farwig N (2014) High conservation value of forest fragments for plant and frugivore communities in a fragmented forest landscape in 
South Africa. Biotropica 46:350-356.

Berhane A, Totland O, Moe SR (2013) Woody plant assemblages in isolated forest patches in a semiarid agricultural matrix. Biodiv Conserv 22:2519-2535.

Berkes F (2009) Community conserved areas: policy issues in historic and contemporary context. Conserv Lett 2:19-24.

Bhagwat SA, Nogue S, Willis KJ (2014) Cultural drivers of reforestation in tropical forest groves of the Western Ghats of India. For Ecol Manage 329:393-400.

Bhagwat SA, Rutte C (2006) Sacred groves: potential for biodiversity management. Frontiers Ecol Environ 4:519-524.

Bongers F, Tennigkeit T (eds) (2010) Degraded Forests in Eastern Africa. Management and Restoration. Earthscan, London. 370 pp.

Brand JS, Butsic V, Schwab B, Kuemmerle T, Radeloff VC (2015) The relative effectiveness of protected areas, a logging ban, and sacred areas for old-growth forest protection in southwest China. Biol Cons 181:1-8.

Brandt JS, Wood EM, Pidgeon AM, Han L-X, Fang Z, Radeloff VC (2013) Sacred forests are keystone structures for forest bird conservation in southwest China's Himalayan Mountains. Biol Conserv 166:34-42.

Burgess ND, Hales JD, Ricketts TH, Dinerstein E (2006) Factoring species, non-species values and threats into biodiversity prioritisation across the ecoregions of Africa and its islands. Biol Conserv 127:383-401.

Campbell MO (2004) Traditional forest protection and woodlots in the coastal savannah of Ghana. Environ Conserv 31:225-232.

Cardelús CL, Lowman MD, Eshete AW (2012) Uniting church and science for conservation. Science 335:915-916.

CDE (1999) EthioGIS, Geospatial information System Ethiopia. Centre for Development and Environment (CDE), University of Bern Switzerland. http://www.wlrceth.org/index.php/wlrc-component/walris-development/ethio-gis

Ceperley N, Montagnini F, Natta A (2010) Significance of sacred sites for riparian forest conservation in Central Benin. Bois Et Forets Des Tropiques:5-23.

Chiarucci A, Bacaro G, Filibeck G, Landi S, Maccherini S, Scoppola A (2012) Scale dependence of plant species richness in a network of protected areas. Biodiv Conserv 21:503-516.

Cordeiro NJ, Borghesio L, Joho MP, Monoski TJ, Mkongewa VJ, Dampf CJ (2015) Forest fragmentation in an African biodiversity hotspot impacts mixed-species bird flocks. Biol Cons 188:61-71.

Crummey D (2000) Land and Society in the Christian Kingdom of Ethiopia from the Thirteenth to the Twentieth Century. University of Illinois Press, Urbana, USA.

Darbyshire I, Lamb H, Umer M (2003) Forest clearance and regrowth in northern Ethiopia during the last 3000 years. Holocene 13:537-546. 
Daye DD, Healey JR (2015) Impacts of land-use change on sacred forests at the landscape scale. Global Ecology and Conservation 3:349-358.

Deng J, Sun P, Zhao F, Han X, Yang G, Feng Y (2016) Analysis of the ecological conservation behavior of farmers in payment for ecosystem service programs in ecoenvironmentally fragile areas using social psychology models. Sci Tot Environm 550:382-390.

Denier L, Scherr S, Shames S, Chatterton P, Hovani L, Stam N (2015) The Little Sustainable Landscapes Book, Global Canopy Programme: Oxford. 158 pp.

Demissew S (1988) The floristic composition of the Menagesha State Forest and the need to conserve such forests in Ethiopia. Mountain Res Dev 8:243-247.

Demissew S, Cribb P, Rasmussen F (2004) Field guide to Ethiopian orchids. Royal Botanic Gardens, Kew.

Dickinson JL, Shirk J, Bonter D, Bonney R, Crain RL, Martin J, Phillips T, Purcell K (2012) The current state of citizen science as a tool for ecological research and public engagement. Front Ecol Environm 10:291-297.

Dudley N, Higgins-Zogib L, Mansourian S (2009) The links between protected areas, faiths, and sacred natural sites. Conserv Biol 23:568-577.

Dudley N, Bhagwat S, Higgins-Zogib L, Lassen B, Verschuuren B, Wild R (2010). Conservation of biodiversity in sacred natural sites in Asia and Africa: a review of the scientific literature. Pages 19-32 in: Verschuuren B, Wild R, McNeely JA, Oviedo G (2010) Sacred Natural Sites. Conserving Nature and Culture. Earthscan, Washington, DC.

Dufrêne M, Legendre P (1997) Species assemblages and indicator species: the need for a flexible asymmetrical approach. Ecol Monogr 67: 345-366.

Ewers RM, Didham RK (2006) Confounding factors in the detection of species responses to habitat fragmentation. Biol Rev 81:117-142.

Fahrig L (2003) Effects of habitat fragmentation on biodiversity. Ann Rev Ecol Evol Syst $34: 487-515$.

Fischer J, Lindenmayer DB (2002) Small patches can be valuable for biodiversity conservation:two case studies on birds in southeastern Australia. Biol Conserv 106:129136.

Fischer J, Lindenmayer DB (2007) Landscape modification and habitat fragmentation: a synthesis. Global Ecol Biogeogr 16:265-280.

Friis I (1992) Forests and Forest Trees of Northeast Tropical Africa - Their Natural Habitats and Distribution Patterns in Ethiopia, Djibouti and Somalia (Kew Bull. Additional Series 15). Her Majesty's Stationary Office, London. 400 pp

Friis I, Demissew S, van Breugel P (2010) Atlas of the potential vegetation of Ethiopia. Biol.Skr. Dan. Vid. Selsk. 58:1-307

Gao H, Ouyang Z, Chen S, van Koppen CSA (2013) Role of culturally protected forests in biodiversity conservation in Southeast China. Biodiv Conserv 22:531-544.

Githiru M, Lens L (2007) Application of fragmentation research to conservation planning for 
multiple stakeholders: an example from the Taita Hills, southeast Kenya. Biol Cons 134:271-278.

Gunaga S, Rajeshwari N, Vasudeva R (2013) Tree diversity and disturbance of kaan forests: Relics of a community protected climax vegetation in the Central Western Ghats. Trop Ecol 54:117-131.

Hanski I (1998) Metapopulation dynamics. Nature 396:41-49

Harris LD (1984) The fragmented forest: island biogeography theory and the preservation of biotic diversity. University of Chicago Press, Chicago.

Hernandez-Ruedas MA, Arroyo-Rodriguez V, Meave JA, Martinez-Ramos M, IbarraManriquez G, Martinez E, Jamangape G, Melo FPL, Santos BA (2014) Conserving tropical tree diversity and forest structure: the value of small rainforest patches in moderately-managed landscapes. PLoS One 9:10.

Hokkanen PJ, Kouki J, Komonen A (2009) Nestedness, SLOSS and conservation networks of boreal herb-rich forests. Appl Veg Sci 12:295-303.

Honnay O, Jacquemyn H (2007) Susceptibility of rare and common plant species to the genetic consequences of habitat fragmentation. Cons Biol 21: 824-831.

Hundera K, Aerts R, Fontaine A, Van Mechelen M, Gijbels P, Honnay O, Muys B (2013) Effects of coffee management intensity on composition, structure, and regeneration status of Ethiopian moist evergreen Afromontane forests. Environ Manage 51:801-809.

IBC (2012) The state of forest genetic resources of Ethiopia. Country report submitted to FAO on the state of forest genetic resources of Ethiopia. Institute for Biodiversity Conservation, Addis Ababa.

Jacob M, Frankl A, Beeckman H, Mesfin G, Hendrickx M, Guyassa E, Nyssen J (2014) North Ethiopian Afro-Alpine tree line dynamics and forest-cover change since the early $20^{\text {th }}$ century. Land Degrad Developm 26:654-664.

Keane A, Ramarolahy AA, Jones JPG, Milner-Gulland EJ (2011) Evidence for the effects of environmental engagement and education on knowledge of wildlife laws in Madagascar. Cons Lett 4:55-63.

Keller LF, Waller DM (2002) Inbreeding effects in wild populations. Trends Ecol Evol 17:230-241.

Kibet S (2011) Plant communities, species diversity, richness, and regeneration of a traditionally managed coastal forest, Kenya. For Ecol Manage 261:949-957.

Kokou K, Adjossou K, Kokutse AD (2008) Considering sacred and riverside forests in criteria and indicators of forest management in low wood producing countries: The case of Togo. Ecol Indic 8:158-169.

Laita A, Monkkonen M, Kotiaho JS (2010) Woodland key habitats evaluated as part of a functional reserve network. Biol Conserv 143:1212-1227.

Lander TA, Boshier DH, Harris SA (2010) Fragmented but not isolated: Contribution of single trees, small patches and long-distance pollen flow to genetic connectivity for Gomortega keule, an endangered Chilean tree. Biol Conserv 143:2583-2590.

Laurance WF (2005) When bigger is better: the need for Amazonian mega-reserves. Trends 
Ecol Evol 20:645-648.

Lemenih M, Bongers F (2010) The role of plantation forests in fostering ecological restoration: experiences from East Africa. In: Bongers F, Tennigkeit T (eds) Degraded Forests in Eastern Africa. Management and Restoration. Earthscan, London, pp. 171219.

McCune B, Keon D (2002) Equations for potential annual direct incident radiation and heat load. J Veg Sci 13:603-606.

McCune B, Mefford MJ (1999) PC-ORD 4.0 for Windows. Multivariate analysis of ecological data. MjM Software, Gleneden Beach, OR, USA.

Metcalfe K, Ffrench-Constant R, Gordon I (2010) Sacred sites as hotspots for biodiversity: the Three Sisters Cave complex in coastal Kenya. Oryx 44:118-123.

Mgumia FH, Oba G (2003) Potential role of sacred groves in biodiversity conservation in Tanzania. Environ Conserv 30:259-265.

Murcia C (1995) Edge effects in fragmented forests - implications for conservation. Trends Ecol Evol 10:58-62.

Myers N, Mittermeier RA, Mittermeier CG, da Fonseca GAB, Kent J (2000) Biodiversity hotspots for conservation priorities. Nature 403:853-858.

Nyssen J, Frankl A, Haile M, Hurni H, Descheemaeker K, Crummey D, Ritler A, Portner B, Nivergelt B, Moeyersons J, Munro N, Deckers J, Billi P, Poesen J (2014)

Environmental conditions and human drivers for changes to north Ethiopian mountain landscapes over 145 years. Sci Total Environ 485:164-179.

Nyssen J, Haile M, Naudts J, Munro N, Poesen J, Moeyersons J, Frankl A, Deckers J, Pankhurst R (2009) Desertification? Northern Ethiopia re-photographed after 140 years. Sci Total Environ 407:2749-2755.

Nyssen J, Petrie G, Mohamed S, Gebremeskel G, Seghers V, Debever M, Hadgu KM, Stal C, Billi P, Demaeyer P, Haile M, Frankl A (2016) Recovery of the aerial photographs of Ethiopia in the 1930s. J Cultural Heritage 17: 170-178.

Nyssen J, Poesen J, Moeyersons J, Deckers J, Haile M, Lang A (2004) Human impact on the environment in the Ethiopian and Eritrean highlands - a state of the art. Earth Sci Rev 64:273-320.

Petheram L, Campbell BM (2010) Listening to locals on payments for environmental services. J Environ Manage 91:1139-1149.

Poudyal M, Ramamonjisoa BS, Hockley N, Rakotonarivo OS, Gibbons JM, Mandimbiniaina R, Rasoamanana A, Jones JPG (2016) Can REDD+ social safeguards reach the 'right' people? Lessons from Madagascar. Glob Environm Change 37:31-42.

Ray R, Chandran MDS, Ramachandra TV (2014) Socio-cultural protection of endemic trees in humanised landscape. Biodiv Conserv 23:1977-1994.

Rutte C (2011) The sacred commons: Conflicts and solutions of resource management in sacred natural sites. Biol Conserv 144:2387-2394.

Schmitt CB, Senbeta F, Denich M, Preisinger H, Boehmer HJ (2010) Wild coffee management and plant diversity in the montane rainforest of southwestern Ethiopia. Afr 
J Ecol 48:78-86.

Sheridan MJ, Nyamweru C (eds) (2007) African Sacred Groves. Ecological Dynamics and Social Change. Ohio University Press. Athens, OH. 240 pp.

Senbeta F, Denich M (2006) Effects of wild coffee management on species diversity in the Afromontane rainforests of Ethiopia. For Ecol Manage 232:68-74.

Struebig MJ, Kingston T, Petit EJ, Le Comber SC, Zubaid A, Mohd-Adnan A, Rossiter SJ (2011) Parallel declines in species and genetic diversity in tropical forest fragments. Ecol Lett 14:582-590.

Tadesse G, Zavaleta E, Shennan C (2014) Coffee landscapes as refugia for native woody biodiversity as forest loss continues in southwest Ethiopia. Biol Conserv 169:384-391.

Tankou CM, de Snoo GR, de Iongh HH, Persoon G (2014) Variation in plant biodiversity across sacred groves and fallows in Western Highlands of Cameroon. Afr J Ecol 52:1019.

Teketay D, Lemenih M, Bekele T, Yemshaw Y, Feleke S, Tadesse W, Moges Y, Hunde T, Nigussie D (2010) Forest resources and challenges of sustainable forest management and conservation in Ethiopia. In: Bongers F, Tennigkeit T (eds) Degraded Forests in Eastern Africa. Management and Restoration. Earthscan, London, pp. 19-63.

Teklehaimanot Z, Healey JR, Binggeli P, Ambrose B, Hall JB, Smith J, Abebe K, Dessisa D, Adane G (2004) Biodiversity conservation in ancient church and monastery yards in Ethiopia. Darwin Initiative for the Survival of Species Final Report, University of Wales, Bangor. Available online at http://www.darwininitiative.org.uk/project/10031/

Telila H, Hylander K, Nemomissa S (2015) The potential of small Eucalyptus plantations in farmscapes to foster native woody plant diversity: local and landscape constraints. Rest Ecol 23:918-926.

TewoldeBerhan S (2003) Vegetation improvement in closed areas, grazing land and protected forest in Tigray, Ethiopia. Diss. M.Sc. Georg-August University, Göttingen, Germany.

Thijs KW, Aerts R, Musila W, Siljander M, Matthysen E, Lens L, Pellikka P, Gulinck H, Muys B (2014) Potential tree species extinction, colonization and recruitment in Afromontane forest relicts. Basic Appl Ecol 15:288-296.

Turner IM, Corlett RT (1996) The conservation value of small, isolated fragments of lowland tropical rain forest. Trends Ecol Evol 11:330-333.

Ullman E (1941) A theory of location for cities. Am J Sociology 46:853-864.

van Breugel P, Friis I, Demissew S, Barnekow Lillesø JP, Kindt R (2015) Current and future fire regimes and their influence on natural vegetation in Ethiopia. Ecosystems doi:10.1007/s10021-015-9938-x

Vandermeer J, Carvajal R (2001) Metapopulation dynamics and the quality of the matrix. Am Nat 158:211-220.

Visco DM, Michel NL, Boyle WA, Sigel BJ, Woltmann S, Sherry TW (2015) Patterns and causes of understorey bird declines in human-disturbed tropical forest landscapes: a case study from Central America. Biol Cons 191:117-129. 
Vranckx G, Jacquemyn H, Muys B, Honnay O (2012) Meta-analysis of susceptibility of woody plants to loss of genetic diversity through habitat fragmentation. Conserv Biol 26:228-237.

Vranckx G, Mergeay J, Cox K, Muys B, Jacquemyn H, Honnay O (2014) Tree density and population size affect pollen flow and mating patterns in small fragmented forest stands of Pedunculate Oak Quercus robur. For Ecol Manage 328:254-261.

Wassie A, Sterck FJ, Bongers F (2010) Species and structural diversity of church forests in a fragmented Ethiopian Highland landscape. J Veg Sci 21:938-948.

Wassie A, Sterck FJ, Teketay D, Bongers F (2009a) Effects of livestock exclusion on tree regeneration in church forests of Ethiopia. For Ecol Manage 257:765-772.

Wassie A, Sterck FJ, Teketay D, Bongers F (2009b) Tree regeneration in church forests of Ethiopia: effects of microsites and management. Biotropica 41:110-119.

WBISPP (2004) Forest Resources of Ethiopia. Woody Biomass Inventory and Strategic Planning Project, Ministry of Agriculture and Rural Development, Addis Ababa. 
SUPPLEMENTARY MATERIAL

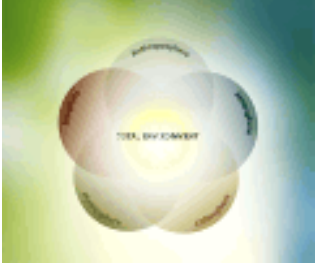

Conservation of the Ethiopian church forests: threats, opportunities and implications for their management

Raf Aerts, Koen Van Overtveld, Eva November, Alemayehu Wassie, Abrham Abiyu, Sebsebe Demissew, Desalegn D. Daye, Kidane Giday, Mitiku Haile, Sarah TewoldeBerhan, Demel Teketay, Zewge Teklehaimanot, Pierre Binggeli, Jozef Deckers, Ib Friis, Georg Gratzer, Martin Hermy, Moïra Heyn, Olivier Honnay, Maxim Paris, Frank J. Sterck, Bart Muys, Frans Bongers, John R. Healey

DOI: $10.1016 / j . s c i t o t e n v .2016 .02 .034$

Fig. S1 Typical landscape in the northern highlands of Ethiopia

Fig. S2 Church forest C249 in the northern highlands of Ethiopia

Fig. S3 Typical landscape in the central highlands of Ethiopia

Fig. S4 Church forest C578 in the central highlands of Ethiopia

Fig. S5 Church forest digitization process

Fig. S6 Deforestation frontier in the central highlands of Ethiopia

Table S1 Indicator species for woody species communities of church forests

Table S2 Spearman rank correlations between NMDS scores and environmental variables 


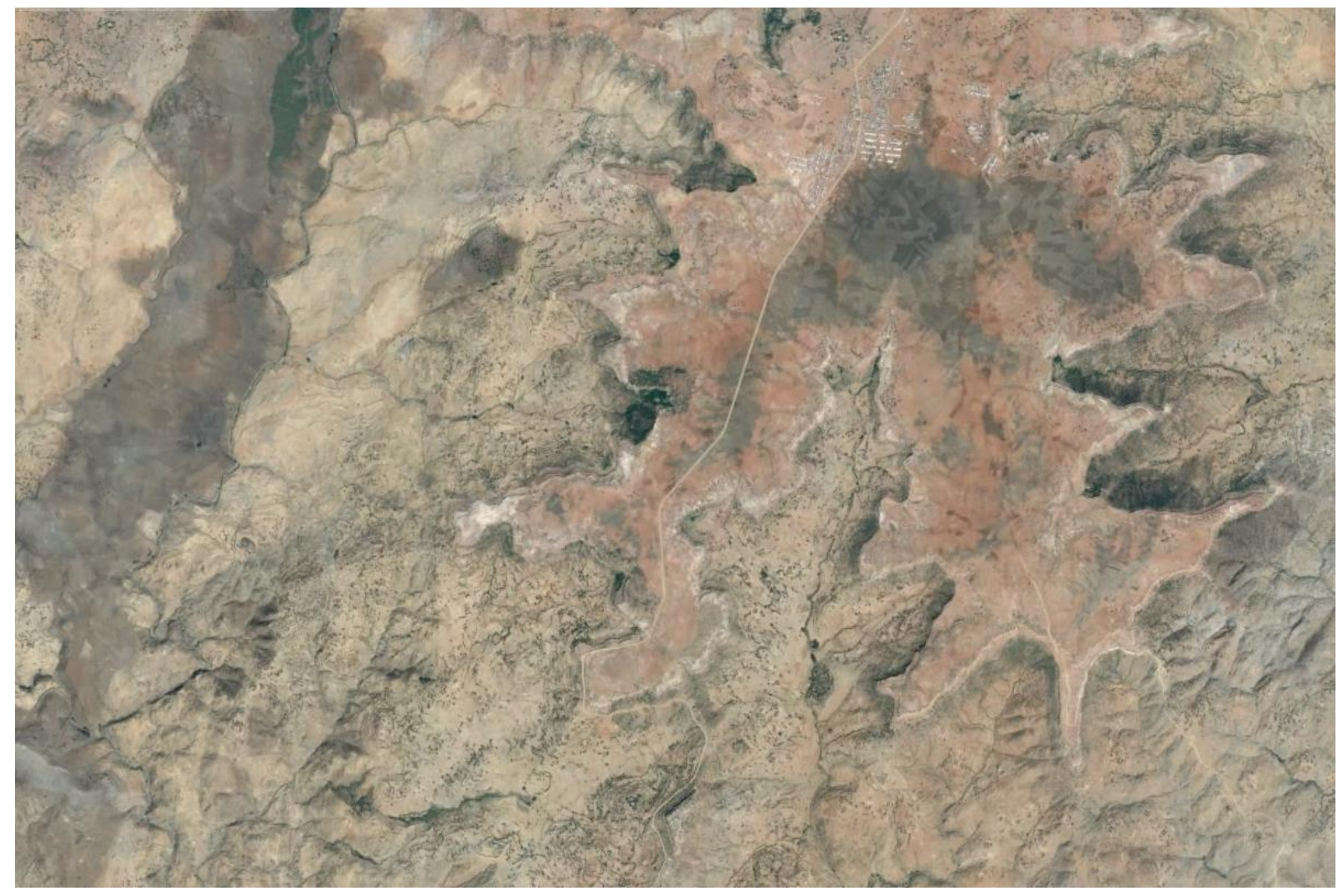

Fig. S1 Typical landscape in the northern highlands of Ethiopia $\left(14^{\circ} 0.8^{\prime} \mathrm{N} 38^{\circ} 46.1^{\prime} \mathrm{E}\right)$. Image (C) 2014 CNES/Astrium by way of Google Earth. Eye altitude $10 \mathrm{~km}$, surface area approximately $9 \times 5 \mathrm{~km}^{2}$. 


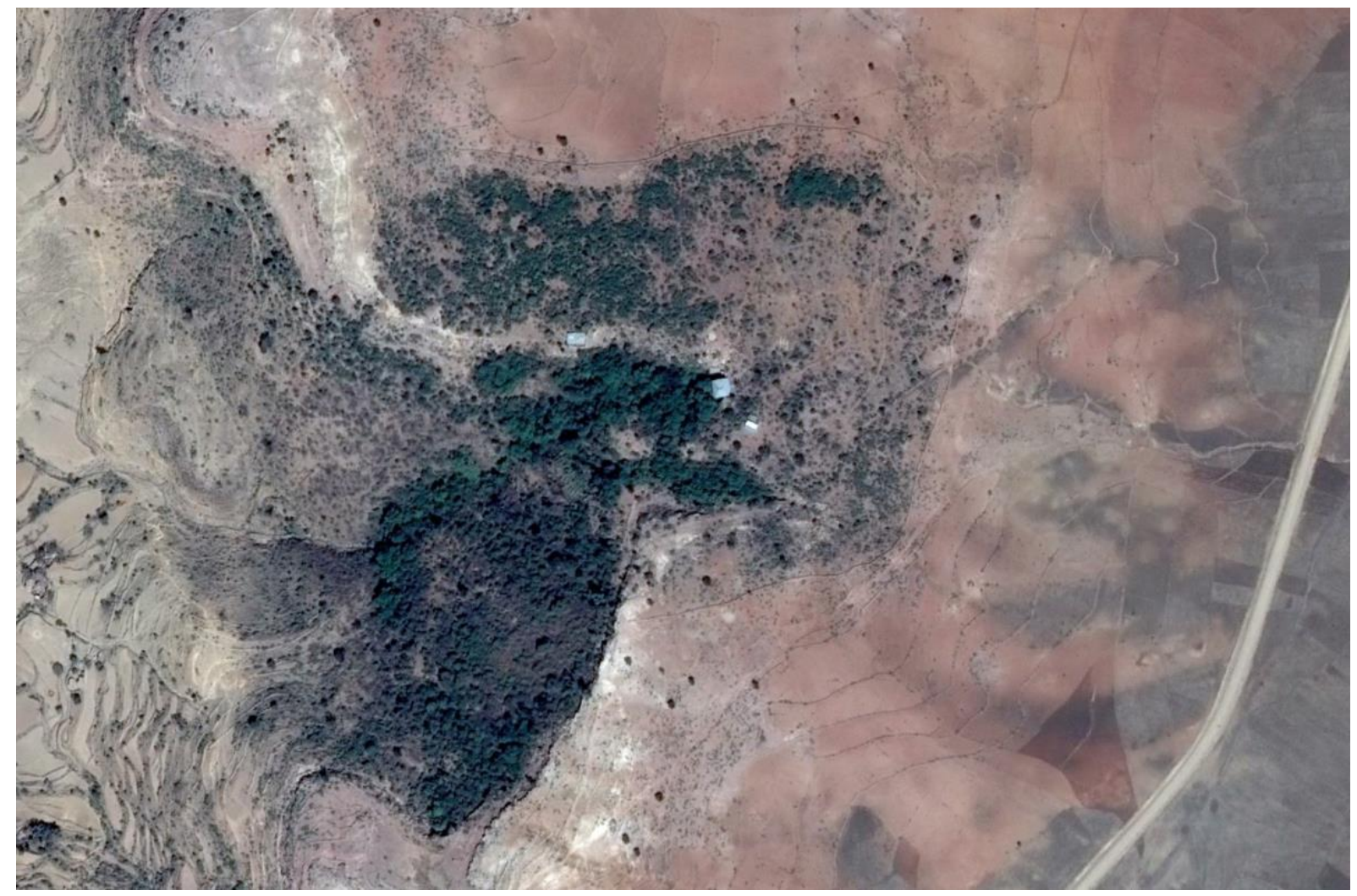

Fig. S2 Church forest C249 in the northern highlands of Ethiopia ( $\left.14^{\circ} 0.8^{\prime} \mathrm{N} 38^{\circ} 46.1^{\prime} \mathrm{E}\right)$, located in the center of Fig. S1. Image (C) 2014 CNES/Astrium by way of Google Earth. Eye altitude $3 \mathrm{~km}$, distance from church to southern edge $370 \mathrm{~m}$. Note irregular shape and highly variable forest quality within the patch. 


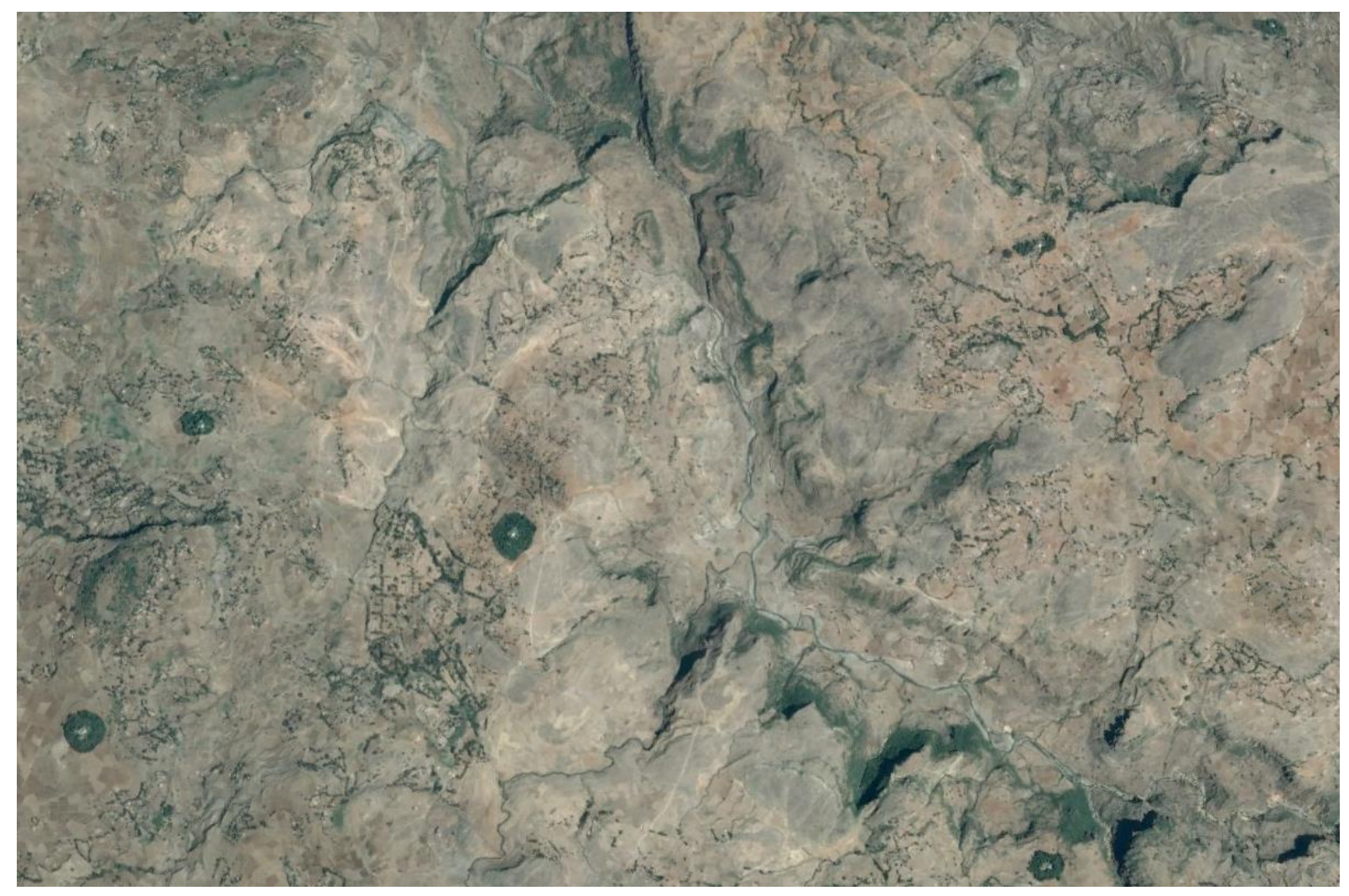

Fig. S3 Typical landscape in the central highlands of Ethiopia $\left(11^{\circ} 54.8^{\prime} \mathrm{N} 38^{\circ} 3.0^{\prime} \mathrm{E}\right)$. Image (C) 2014 CNES/Astrium by way of Google Earth. Eye altitude $10 \mathrm{~km}$, surface area approximately $9 \times 5 \mathrm{~km}^{2}$. The average distance between the three church forests on the left of the image is $2.1 \mathrm{~km}$. 


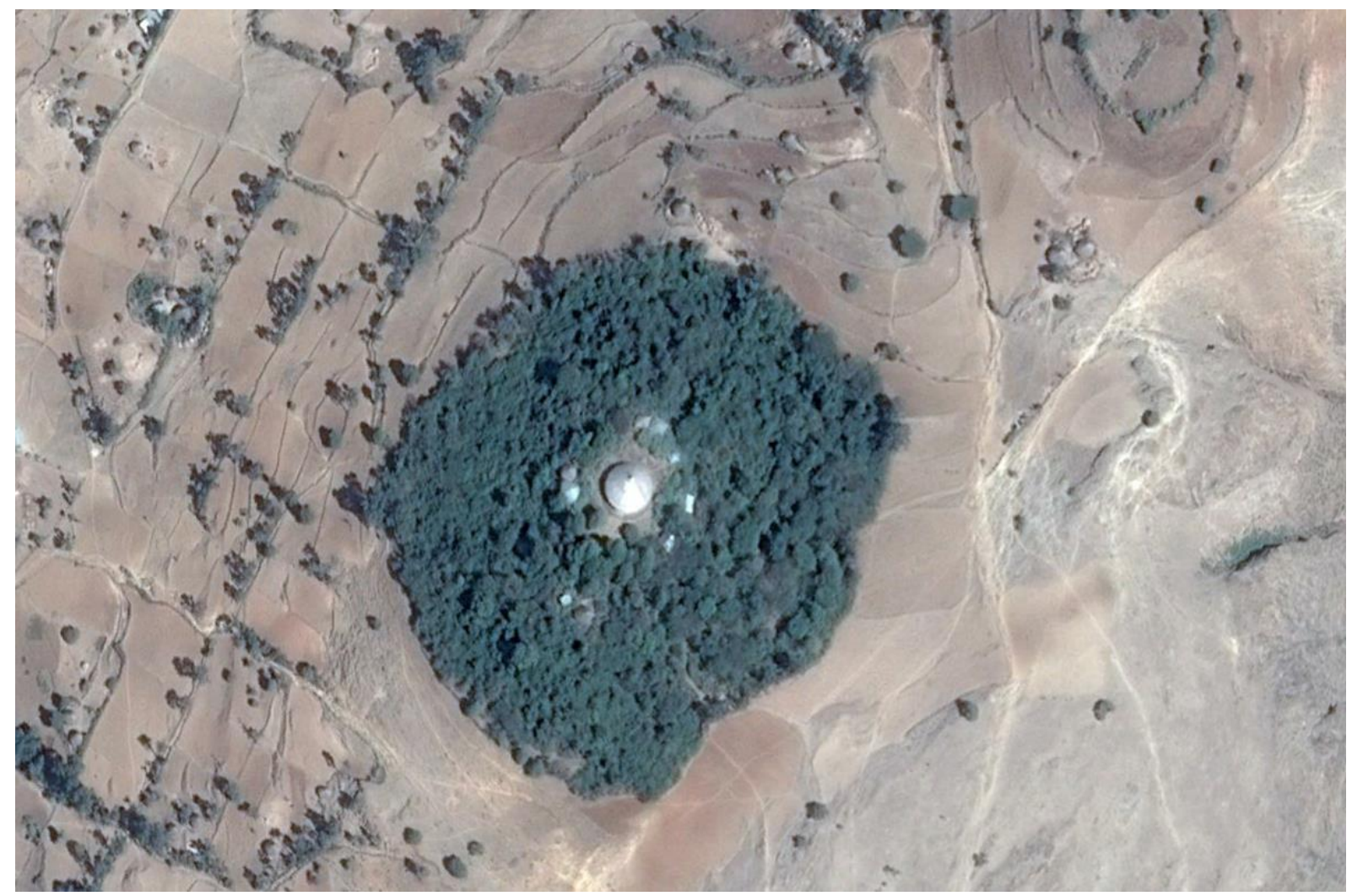

Fig. S4 Church forest C578 in the central highlands of Ethiopia ( $\left.11^{\circ} 54.8^{\prime} \mathrm{N} 38^{\circ} 3.0^{\prime} \mathrm{E}\right)$ located in the center of Fig. S3. Image (C) 2014 CNES/Astrium by way of Google Earth. Eye altitude $3 \mathrm{~km}$, patch radius $120 \mathrm{~m}$. Note regular shape, central location of the church and almost uniform quality throughout the patch. 

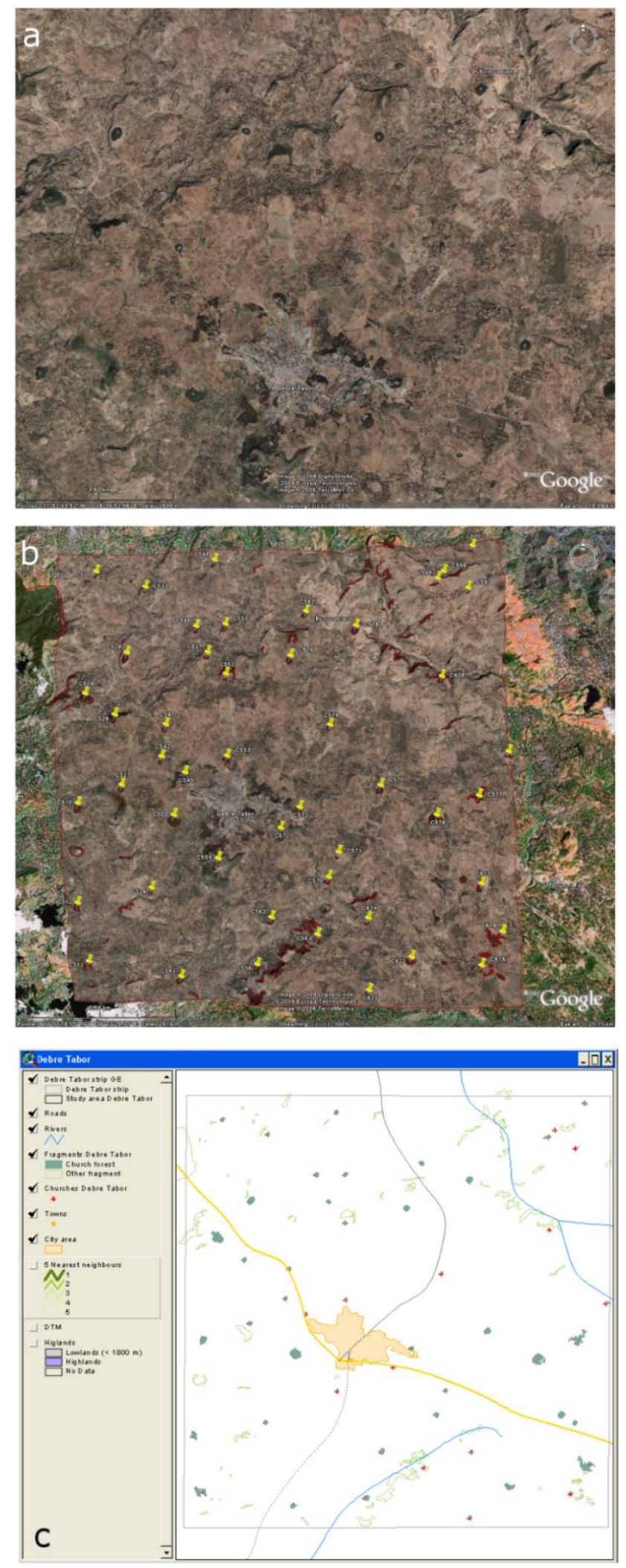

Fig. S5 High spatial resolution images in Google Earth (a) were digitized on screen (b) and via KML format imported into ArcView GIS (c). Digitized boundaries are not part of the Google Earth source material but an interpretation of the authors and therefore do not inherit any copyright from the source material. 


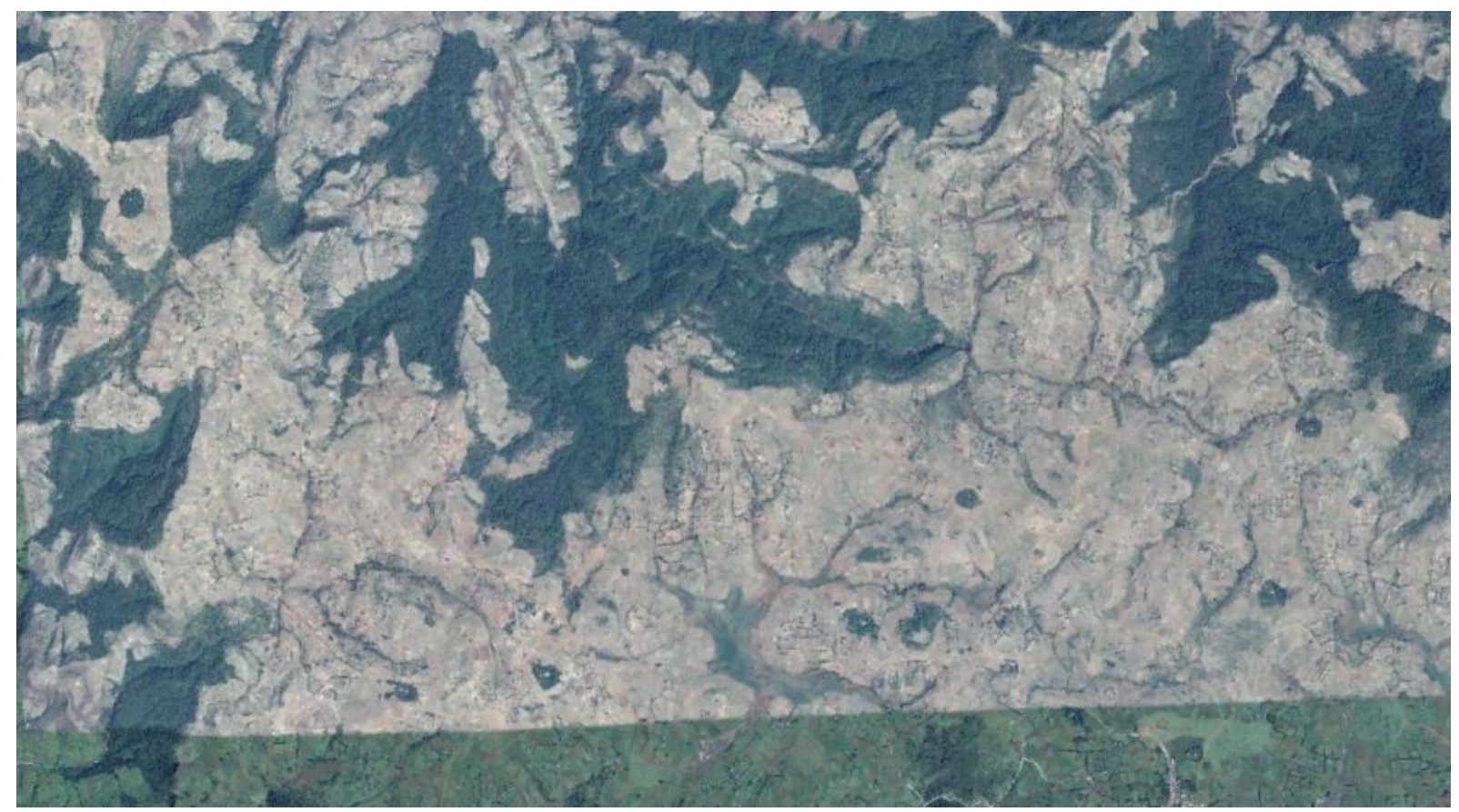

Fig. S6 Deforestation frontier in the central highlands of Ethiopia $\left(10^{\circ} 50.9^{\prime} \mathrm{N} 36^{\circ} 33.6^{\prime} \mathrm{E}\right)$. Image (C 2014 CNES/Astrium by way of Google Earth. Eye altitude $15 \mathrm{~km}$, east-west extent $\sim 17 \mathrm{~km}$, image date 03/01/2014. In the deforested landscape in the southern half of the image forest vegetation only persists in church forests, while in the northern half larger blocks of forest are still present (image date 03/01/2014). Note the almost grid-like pattern of church forests in the south and the process of isolation ongoing in the upper left corner of the image. 


\section{Table S1}

Indicator species for woody species communities of church forests in the dry evergreen Afromontane forest and grassland complex zone of Ethiopia produced by cluster and indicator species analysis.

\begin{tabular}{|c|c|c|c|c|c|c|c|}
\hline \multicolumn{4}{|c|}{ Dry single-dominant Afromontane forest } & \multicolumn{4}{|c|}{ Undifferentiated Afromontane forest } \\
\hline \multicolumn{2}{|l|}{ Olea-Acacia $(N=10)$} & \multicolumn{2}{|c|}{ Juniperus-Olea $(N=22)$} & \multicolumn{2}{|l|}{ Juniperus $(N=21)$} & \multicolumn{2}{|c|}{ Juniperus-Afrocarpus $(N=23)$} \\
\hline Rhus natalensis $^{\mathrm{S}}$ & $86(<0.001)$ & Cordia africana $^{\mathrm{T}}$ & $25(0.015)$ & Vernonia myriantha $^{\mathrm{S}}$ & $67(<0.001)$ & Vernonia auriculifera $^{\mathrm{S}}$ & $66(<0.001)$ \\
\hline Euclea racemosas & $50(<0.001)$ & Dodonaea sp. ${ }^{\mathrm{s}}$ & $25(0.05)$ & Urera hypselodendron ${ }^{\mathrm{s}}$ & $57(<0.001)$ & Allophylus abyssinicus ${ }^{\mathrm{T}}$ & $55(<0.001)$ \\
\hline Cassia sp. ${ }^{\mathrm{s}}$ & $50(<0.001)$ & Ficus vasta ${ }^{\mathrm{T}}$ & $23(0.039)$ & Osyris sp. ${ }^{\mathrm{s}}$ & $45(<0.001)$ & Bersama abyssinica $^{\mathrm{T}}$ & $51(<0.001)$ \\
\hline Psiadia punctulata $^{\mathrm{T}}$ & $30(<0.001)$ & Rydingia integrifolia ${ }^{\mathrm{S}}$ & $19(0.036)$ & Canthium oligocarpum ${ }^{\mathrm{s}}$ & $45(<0.001)$ & Dovyalis abyssinica $^{\mathrm{T}}$ & $46(<0.001)$ \\
\hline Combretum collinum $^{\mathrm{T}}$ & $30(<0.001)$ & Acacia polyacantha ${ }^{\mathrm{T}}$ & $19(0.042)$ & Clausena anisata $^{\mathrm{T}}$ & $41(<0.001)$ & Jasminum stans ${ }^{\mathrm{s}}$ & $44(<0.001)$ \\
\hline Leucas sp. ${ }^{\mathrm{s}}$ & $28(<0.001)$ & Rhus pyroides ${ }^{\mathrm{s}}$ & $18(0.026)$ & Buddleja polystachya ${ }^{\mathrm{T}}$ & $40(0.001)$ & Euphorbia candelabrum ${ }^{\mathrm{T}}$ & $37(<0.001)$ \\
\hline Faidherbia albida ${ }^{\mathrm{T}}$ & $26(<0.001)$ & & & Euphorbia abyssinica $^{\mathrm{T}}$ & $38(0.001)$ & Ekebergia capensis ${ }^{\mathrm{T}}$ & $37(0.002)$ \\
\hline \multirow[t]{8}{*}{ Acacia seyal $^{\mathrm{T}}$} & $14(0.044)$ & & & Dombeya torrida ${ }^{\mathrm{T}}$ & $36(<0.001)$ & Pavetta spp. ${ }^{\mathrm{S}}$ & $34(0.002)$ \\
\hline & & & & Rosa abyssinica ${ }^{\mathrm{s}}$ & $35(0.004)$ & Maytenus obscura $^{\mathrm{T}}$ & $32(0.002)$ \\
\hline & & & & Maytenus arbutifolia $^{\mathrm{T}}$ & $35(0.009)$ & Maytenus gracilipes ${ }^{\mathrm{T}}$ & $31(0.002)$ \\
\hline & & & & Schrebera alata ${ }^{\mathrm{T}}$ & $34(0.001)$ & Vepris nobilis $\mathrm{s}^{\mathrm{s}}$ & $28(0.004)$ \\
\hline & & & & Juniperus procera ${ }^{\mathrm{T}}$ & $32(0.020)$ & Afrocarpus falcatus ${ }^{\mathrm{T}}$ & $28(0.005)$ \\
\hline & & & & Albizia schimperiana ${ }^{\mathrm{T}}$ & $31(0.003)$ & Vernonia leopoldii $^{\mathrm{s}}$ & $27(0.003)$ \\
\hline & & & & Schefflera abyssinica ${ }^{\mathrm{T}}$ & $30(0.001)$ & Blumea elatiors $^{\mathrm{s}}$ & $27(0.009)$ \\
\hline & & & & Erythrina brucei ${ }^{\mathrm{T}}$ & $28(0.006)$ & Brucea antidysenterica $^{\mathrm{T}}$ & $27(0.022)$ \\
\hline
\end{tabular}




\begin{tabular}{|c|c|c|c|}
\hline Ritchiea albersii ${ }^{\mathrm{S}}$ & $28(0.005)$ & Maesa lanceolatas & $25(0.015)$ \\
\hline Teclea nobilis ${ }^{\mathrm{s}}$ & $28(0.014)$ & Ficus sur ${ }^{\mathrm{T}}$ & $24(0.018)$ \\
\hline Rhus glutinosa $a^{\mathrm{S}}$ & $28(0.023)$ & Discopodium penninervium $^{\mathrm{s}}$ & $24(0.018)$ \\
\hline Syzygium guineense ${ }^{\mathrm{T}}$ & $25(0.004)$ & Galiniera saxifragas & $23(0.020)$ \\
\hline Hypericum revolutum ${ }^{\mathrm{T}}$ & $24(0.002)$ & Euphorbia depauperata ${ }^{\mathrm{T}}$ & $22(0.019)$ \\
\hline Combretum molle ${ }^{\mathrm{T}}$ & $22(0.012)$ & Albizia gummifera ${ }^{\mathrm{T}}$ & $22(0.019)$ \\
\hline Rhus vulgaris ${ }^{\mathrm{S}}$ & $22(0.016)$ & Rubus steudneri $^{\mathrm{s}}$ & $22(0.020)$ \\
\hline Millettia ferruginea ${ }^{\mathrm{T}}$ & $21(0.042)$ & Rytigynia neglectas & $22(0.022)$ \\
\hline Ficus ovata $^{\mathrm{T}}$ & $19(0.028)$ & Dracaena afromontana ${ }^{\mathrm{T}}$ & $18(0.043)$ \\
\hline & & Maytenus undata ${ }^{\mathrm{T}}$ & $17(0.042)$ \\
\hline
\end{tabular}

The indicator values range from zero (no indication) to 100 (perfect indication). $p$-values (in parantheses) are calculated from a Monte Carlo permutation test for each species. Superscripts indicate life forms: trees

(T) and shrubs (S). Only species with a significant indicator value $(p<0.05)$ are shown. 


\section{Table S2}

Spearman rank correlations between NMDS scores and environmental variables for church forests in the dry evergreen Afromontane forest and grassland complex zone of Ethiopia $(N=76)$.

\begin{tabular}{|c|c|c|c|c|}
\hline & \multicolumn{2}{|c|}{ NMDS1 $\left(\mathrm{R}^{2}=0.380\right)$} & \multicolumn{2}{|c|}{ NMDS2 $\left(\mathrm{R}^{2}=0.263\right)$} \\
\hline & $R_{S}$ & $p$ & $R_{S}$ & $p$ \\
\hline Degrees north & -0.568 & $<0.001^{*}$ & 0.058 & 0.617 \\
\hline Degrees east & -0.465 & $<0.001 *$ & 0.382 & $0.001 *$ \\
\hline Elevation & 0.294 & 0.010 & 0.679 & $<0.001^{*}$ \\
\hline Mean annual precipitation & 0.638 & $<0.001 *$ & 0.080 & 0.494 \\
\hline Distance to rivers & 0.203 & 0.079 & 0.036 & 0.755 \\
\hline Distance to roads & -0.063 & 0.586 & 0.196 & 0.089 \\
\hline Distance to towns & -0.416 & $<0.001 *$ & 0.022 & 0.847 \\
\hline Urban and rural population & 0.380 & $0.001 *$ & -0.016 & 0.888 \\
\hline Slope & -0.061 & 0.603 & 0.171 & 0.139 \\
\hline Heat load & 0.070 & 0.549 & 0.160 & 0.893 \\
\hline
\end{tabular}

*Spearman rank correlation coefficients $R_{S}$ between NMDS scores and environmental variables need to be evaluated against a corrected $\alpha_{\text {corr }}=0.005$ to assure an overall significance of $\alpha=0.05$ (Bonferroni correction for ten tests). 